\title{
Influence of Mix Proportions on Rheological Properties, Air Content of Wet Shotcrete-A Case Study
}

\author{
Jun Xie ${ }^{1,2,3}$, Xiangfei Cui ${ }^{1,2, *}$, Nan Guo ${ }^{1,3}$ and Guoming Liu $1,2,3, *$ (D) \\ 1 College of Energy and Mining Engineering, Shandong University of Science and Technology, \\ Qingdao 266590, China; xiejunsdust@sdust.edu.cn (J.X.); felixwzshi@gmail.com (N.G.) \\ 2 State Key Laboratory of Strata Intelligent Control and Green Mining Co-founded by Shandong Province and \\ the Ministry of Science and Technology, Qingdao 266590, China \\ 3 College of Safety and Environmental Engineering, Shandong University of Science and Technology, \\ Qingdao 266590, China \\ * Correspondence: skd994394@sdust.edu.cn (X.C.); skd995978@sdust.edu.cn (G.L.)
}

Citation: Xie, J.; Cui, X.; Guo, N.; Liu, G. Influence of Mix Proportions on Rheological Properties, Air Content of Wet Shotcrete-A Case Study. Appl. Sci. 2021, 11, 3550. https://doi.org/ 10.3390/app11083550

Academic Editor: José A. Orosa

Received: 13 March 2021

Accepted: 13 April 2021

Published: 15 April 2021

Publisher's Note: MDPI stays neutral with regard to jurisdictional claims in published maps and institutional affiliations.

Copyright: (C) 2021 by the authors Licensee MDPI, Basel, Switzerland. This article is an open access article distributed under the terms and conditions of the Creative Commons Attribution (CC BY) license (https:// creativecommons.org/licenses/by/ $4.0 /)$.

\begin{abstract}
To study the influence of different mix proportions on the fresh properties of wet shotcrete, the rheological properties and air content of wet shotcrete with different admixtures before pumping were measured. In addition, the pressure drop along the pipeline and the build-up thickness were studied, and the relationship between the rheological properties and the pumpability and sprayability was discussed. This paper attempts to reveal the influence mechanism of admixtures on the fluidity of wet shotcrete by means of pictures. The results show that free paste effect and ball effect are two key factors that affect the performance of fresh wet shotcrete. Air-entraining agent and fly ash are commonly used admixtures, which improve the pumping performance and spraying performance. Finally, the mix proportions of wet shotcrete are put forward to meet the requirements of different types of shotcrete.
\end{abstract}

Keywords: wet shotcrete; mix proportion; fresh properties; air content

\section{Introduction}

Wet shotcrete is a kind of self-compacting concrete technology, in which fresh wet shotcrete is pumped into the pipeline, and then sprayed onto the receiving surface under the function of compressed air [1-7]. Wet shotcrete is widely used in the construction industry, such as slope maintenance and underground space engineering. Especially in the complex coal mine roadway, compared with dry mix shotcrete, wet shotcrete has the advantages of low dust concentration and less rebound, which reduces the mining hazards such as pneumoconiosis.

In the application of wet shotcrete, the pumping process is the initial important process to ensure successful conveying without blockage. Pumpability refers to the pumping capacity of fresh wet shotcrete, i.e., fresh concrete should have proper fluidity and stability when transported through pipes under pressure. At present, a lot of research has been devoted to the study of measurement techniques that evaluate the pumpability of fresh concrete. Especially in the field of self-compacting concrete, rheological and tribological properties of fresh concrete have been recognized as two key factors that affect the pumping performance of fresh concrete $[7,8]$.

Fresh concrete ingredients affect the rheological properties. Literature [8] reviewed the effects of internal components of fresh concrete and external admixtures on rheological properties, including cement, fly ash, slag, silica fume, limestone powder, coarse and fine aggregates, and admixtures (water-reducing agent, viscosity agent, and air-entraining agent). Dils et al. $[9,10]$ studied the effect of cement fineness and chemical composition on the rheological properties of concrete, and pointed out that the larger the surface area of the cement, the higher the content of tricalcium aluminate and alkali, the worse the working 
performance of fresh concrete. Koehler et al. [11] found that the increase of cement paste content reduced the plastic viscosity and yield stress of fresh concrete; especially for mixtures with large differences in aggregate shapes and poor particle gradation, and increasing the cement paste content has a positive effect on concrete pumping. Choi et al. [12] studied the effect of different coarse aggregate sizes on the rheological properties of fresh concrete, as the aggregate size increases, the plastic viscosity increased. Xu et al. [13] studied the rheological and mechanical property of fresh cemented materials incorporating silica fume, and assessed the applicability of using silica fume as a partial cement replacement. Park et al. [14] obtained through experiments: the rheological parameters (plastic viscosity and shear stress) of fresh concrete mixed with fly ash are lower than those of concrete without fly ash. In addition, with the increase of fly ash content increases, the plastic viscosity and shear stress gradually increase. The addition of silica fume increases the plastic viscosity and yield stress of the fresh concrete, and enhances the flocculation inside the concrete $[15,16]$. Yun et al. $[17,18]$ used the IBB rheometer to measure the influence of mineral admixtures on the performance of wet shotcrete, and concluded that the pumpability and shotcretability of fresh concrete can be improved by adding silica fume and fly ash at the same time.

In the early stage, slump and pressure bleeding tests were combined to predict the pumpability of fresh concrete $[19,20]$. However, the good slump cannot guarantee good pumping performance in field application. Burns [21] studied the pumping pressure according to the rheological and tribological characteristics of fresh wet shotcrete moving in small diameter hose. Based on the full-scale pumping test, Feys et al. [22] analyzed the influence of fresh concrete rheology, tribology, pipe radius, and flow rate on pumping pressure. Gołaszewski [23] pointed out that according to the test results of BT2 rheometer, the change of rheological properties of fresh concrete with time could be estimated based on the rheological properties of corresponding mortar. Concrete flow in pipes can be summarized as a combination of three flow types, including lubrication layer shear, shear flow and plug flow [24-27]. Secrieru et al. $[19,28]$ indicated that the pumping performance of fresh concrete depends on the formation of the lubricating layer and the rheological properties of concrete plug. Mixing various chemical admixtures or mineral additives can have a significant impact on the rheological properties of concrete, thus affecting the pumping performance, at the same time, improving the stability of the mixture, and even changing the thickness of the lubrication layer [28,29]. However, the differences in the composition of mineral additives or chemical admixtures lead to different rheological properties. According to the previous experiments and literature, the pumping performance and sprayability can be estimated by rheological parameters. For example, higher flow resistance (yield shear stress) means better sprayability and poorer pumpability.

To study the rheological properties of wet shotcrete with different admixtures and further estimate the pumpability and shotcreting performance before pumping, this paper studies the influence of water-binder ratio $(\mathrm{w} / \mathrm{b}, \mathrm{WC})$, sand ratio (SR), fiber length (FI), air-entraining agent (AE), water-reducing agent (WR), silica fume (SF) and fly ash (FA) on the rheological properties and air content of wet shotcrete. The influence mechanism of admixtures on the properties of fresh concrete is discussed. By comparing the effect of fly ash, silica fume, and other admixtures, the application of wet shotcrete is improved. It is hoped that this study may provide a useful information for improving the pumping and spraying properties of fresh wet shotcrete and further improving the quality of wet shotcrete. Through this research, the main goal is to provide a simplified guide for shotcrete technologists. 


\section{Materials and Methods}

\subsection{Materials}

Table 1 shows the mix proportions. Cement is the ordinary Portland cement (OPC) Po. 42.5, specific gravity 3.14. The F grade fly ash with specific gravity of 2.34 is selected in this test. These two chemical compositions are shown in Table 2. The particle size distribution of cement, fly ash and silica fume was reported in [30]. Please note that these mix proportions are based on previous tests and published literature [2,3,31-36]. Due to the different characteristics of raw materials from different sources, the mix proportion is adjusted according to ACI 506R-16 of "Shotcrete Guidelines" [37]. For example, the selected water-binder ratio is slightly higher.

Table 1. Mixture proportions of fresh wet shotcrete.

\begin{tabular}{|c|c|c|c|c|c|c|c|c|c|c|}
\hline No. & Variable & $\begin{array}{l}\text { WC } \\
(w / b)\end{array}$ & $\begin{array}{c}\text { Water } \\
\left(\mathrm{kg} / \mathrm{m}^{3}\right)\end{array}$ & SR(\%) & $\begin{array}{c}\text { Sand } \\
\left(\mathrm{kg} / \mathrm{m}^{3}\right)\end{array}$ & $\begin{array}{c}\text { FI } \\
(\mathrm{mm})\end{array}$ & $\begin{array}{c}\text { AEA } \\
(\%)\end{array}$ & $\begin{array}{l}\text { WR } \\
(\%)\end{array}$ & $\begin{array}{l}\text { SF } \\
(\%)\end{array}$ & $\begin{array}{l}\text { FA } \\
(\%)\end{array}$ \\
\hline WC45 & \multirow{4}{*}{$\begin{array}{l}\text { Water-binder } \\
\text { ratio } \\
(\mathrm{WC})\end{array}$} & 0.45 & 198 & 70 & 1100 & & & 0.3 & & \\
\hline WC50 & & 0.5 & 220 & 68 & 1080 & & & & & \\
\hline WC55 & & 0.55 & 242 & 66 & 1070 & & & & & \\
\hline WC60 & & 0.6 & 264 & 66 & 1050 & & & & & \\
\hline SR50 & \multirow{3}{*}{$\begin{array}{l}\text { Sand ratio } \\
\text { (SR) }\end{array}$} & 0.5 & 220 & 50 & 900 & & & & & \\
\hline SR60 & & 0.5 & 220 & 60 & 1000 & & & & & \\
\hline SR70 & & 0.5 & 220 & 70 & 1100 & & & 0.3 & & \\
\hline FI6 & \multirow{3}{*}{$\begin{array}{l}\text { Fiber } \\
(\mathrm{FI})\end{array}$} & 0.5 & 220 & 60 & 1000 & 6 & & 0.3 & & \\
\hline FI12 & & 0.5 & 220 & 60 & 1000 & 12 & & 0.3 & & \\
\hline FI29 & & 0.5 & 220 & 60 & 1000 & 29 & & 0.3 & & \\
\hline $\mathrm{AE} 0.02 \%$ & \multirow{3}{*}{$\begin{array}{c}\text { Air-entraining } \\
\text { agent (AEA) }\end{array}$} & 0.5 & 220 & 60 & 1000 & & 0.02 & & & \\
\hline AE $0.04 \%$ & & 0.5 & 220 & 60 & 1000 & & 0.04 & & & \\
\hline AE $0.06 \%$ & & 0.5 & 220 & 60 & 1000 & & 0.06 & & & \\
\hline WR0.3\% & \multirow{4}{*}{$\begin{array}{l}\text { Water reducer } \\
\quad(\mathrm{WR})\end{array}$} & 0.5 & 220 & 60 & 1000 & & & 0.3 & & \\
\hline WR0.6\% & & 0.5 & 220 & 60 & 1000 & & & 0.6 & & \\
\hline WR0.9\% & & 0.5 & 220 & 60 & 1000 & & & 0.9 & & \\
\hline WR1.2\% & & 0.5 & 220 & 60 & 1000 & & & 1.2 & & \\
\hline SF5\% & \multirow{3}{*}{$\begin{array}{l}\text { Silica fume } \\
\text { (SF) }\end{array}$} & 0.5 & 220 & 60 & 1000 & & & 0.3 & 5 & \\
\hline SF10 $\%$ & & 0.5 & 220 & 60 & 1000 & & & 0.3 & 10 & \\
\hline SF15\% & & 0.5 & 220 & 60 & 1000 & & & 0.3 & 15 & \\
\hline FA5\% & \multirow{3}{*}{$\begin{array}{l}\text { Fly ash } \\
\text { (FA) }\end{array}$} & 0.5 & 220 & 60 & 1000 & & & & & 5 \\
\hline FA $10 \%$ & & 0.5 & 220 & 60 & 1000 & & & & & 10 \\
\hline FA15\% & & 0.5 & 220 & 60 & 1000 & & & & & 15 \\
\hline
\end{tabular}

Table 2. Chemical compositions of cement and fly ash (unit: \%).

\begin{tabular}{ccccccc}
\hline $\begin{array}{c}\text { Raw } \\
\text { Materials }\end{array}$ & $\mathrm{SiO}_{2}$ & $\mathrm{AI}_{\mathbf{2}} \mathbf{O}_{3}$ & $\mathrm{Fe}_{\mathbf{2}} \mathbf{O}_{3}$ & $\mathbf{C a O}$ & $\mathbf{M g O}$ & $\mathbf{S O}_{3}$ \\
\hline Cement & 19.5 & 6.45 & 3.08 & 57.57 & 1.21 & 2.01 \\
Fly ash & 43.64 & 25.39 & 4.19 & 5.62 & 0.84 & 0.28 \\
Silica fume & 95 & 1.1 & 0.8 & 0.3 & 0.6 & - \\
\hline
\end{tabular}

In this study, silica fume with specific gravity of 2.21 and specific surface area of $160,000-300,000 \mathrm{~cm}^{2} / \mathrm{g}$ were used. The silica fume is composed of up to $95 \% \mathrm{SiO}_{2}$ and less than $1 \% \mathrm{CaO}$, as listed in Table 2. In this study, natural river sand was used as fine aggregate with fineness modulus of 2.66. For coarse aggregate, gravel with a maximum size of $10 \mathrm{~mm}$ is used, the fineness modulus is 5.70 . The specific gravity of sand and gravel are 2.61 and 2.67, respectively. At the same time, the water absorption of fine aggregate and coarse aggregate is considered to modify the mixed water. The aggregate grading curve conforms to the national standard GB50086-2001. In this study, polypropylene fiber (FI) 
with specific gravity of 0.93 was used. The fiber diameter range was $18-48 \mu \mathrm{m}$, and the fiber content in shotcrete was $0.9 \mathrm{~kg} / \mathrm{m}^{3}$. The tensile strength and elastic modulus of the fiber are more than $500 \mathrm{MPa}$ and $3850 \mathrm{MPa}$, respectively. Polycarboxylate water reducer (WR) and 126A type air-entraining agent (AEA) were mixed into wet shotcrete respectively. The water-reducing rate of the water reducer is about $24 \%$. Admixtures are marked as \%, indicating the percentage of the admixture relative to the binder content (mass). Each fresh concrete sample was produced in a horizontal axis forced mixer. The mixing process is as follows: first mixing coarse aggregate and sand, then adding cement, fly ash, fiber and silica fume in $20 \mathrm{~s}$, and then adding water and other additives in $2 \mathrm{~min}$.

\subsection{Measurement of Rheological Properties of Wet Shotcrete}

The rheological properties of fresh wet shotcrete were tested by eBT2 rheometer. This rheometer is different from the coaxial cylinder rational viscometer. Figure 1a shows the structure of eBT2, including a shaft decoder and two moment sensitive probes. The smart phone controls the rheometer through Bluetooth interface. It has been confirmed that the behavior of fresh concrete is similar to Bingham fluid (Equation (1)), where $\tau(\mathrm{Pa})$ is the shear stress, $\tau_{0}(\mathrm{~Pa})$ is the yield stress, and $\eta(\mathrm{Pa} \cdot \mathrm{s})$ is the plastic viscosity [38-41]. The corresponding relationship can be expressed by Equation (2), where g (Nm) and H (Ns) are flow resistance and torque viscosity respectively, which are called relative yield stress and relative plastic viscosity $[42,43]$. The rheometer can determine the flow resistance and torque viscosity according to the measurement of momentum and rotation speed. Due to the double probe structure and the special operation in the measurement process, the problems of segregation and structural breakdown in the measurement process are avoided. The rules and methods of using this rheometer were showed in detail in [44-47]. The rotational speed setting during the rheological test is shown in Figure 1b. One rotation time is $30 \mathrm{~s}$.

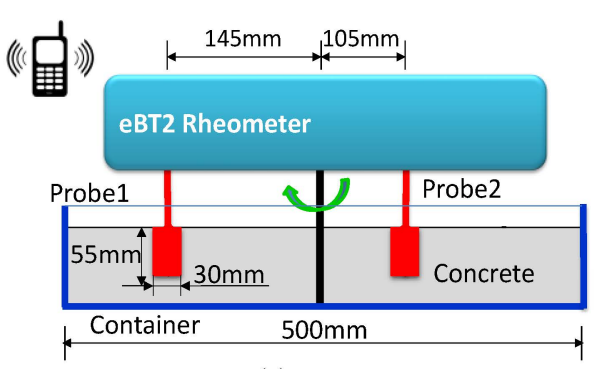

(a)

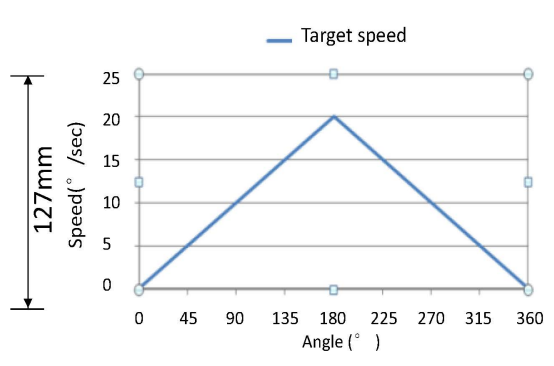

(b)

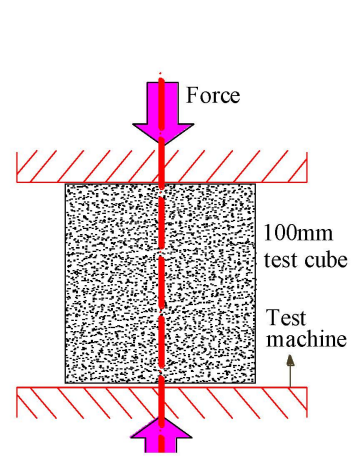

(c)

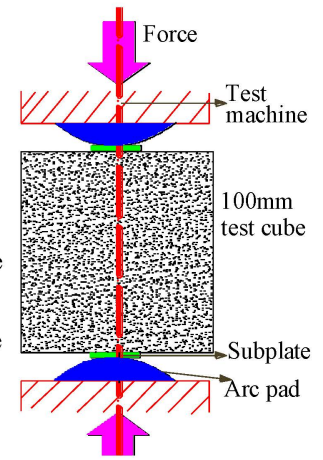

(d)

Figure 1. Schematic diagram of eBT2 rheometer (a), rotational speed (b), compressive test (c) and splitting test (d).

$$
\begin{gathered}
\tau=\tau_{0}+\eta \dot{\gamma} \\
T=g+h N
\end{gathered}
$$

\subsection{Air Content and Slump Test}

The air content of fresh concrete was measured by LA-0316 type air content meter. The air content measuring instrument is composed of base, vent valve, pressure chamber, and pressure gauge. The air content value can be read directly from the pressure gauge. Slump value was measured by slump cone. Two tests were carried out according to the requirements of Chinese standard GB/T50086-2016. Measurement method of air content: (1) Fill base with concrete and strike off. Clean cover and base rim; clamp together. (2) Open petcocks. Use syringe to inject water through one petcock until water is expelled from opposite petcock. (3) Close air bleeder value on air chamber. Pump up air initial pressure line gauge. Wait a few seconds, tap gauge lightly. If necessary, add or 
release air to attain reading at initial pressure line. Close petcocks. (4) Press needle valve lever to release air into base. Continue pressing lever and lightly tap gauge. Read direct percentage of air. (5) Thoroughly clean base, cover, and petcock openings with running water. Measurement method of slump: The slump is measured by the slump cone, which is a $300 \mathrm{~mm}$ high trumpet shaped drum. Pour concrete into the slump cone and fill it in three times. After each filling, use a tamping hammer to strike 25 times from the outside to the inside along the wall of the cone. After tamping, level it. Then pull up the slump cone vertically, and the fresh concrete will collapse due to its own weight. The slump value is obtained by subtracting the height of the cone from the height of the highest point of the collapsed concrete.

\subsection{Measurement of Hardenability}

To evaluate the mechanical properties of wet shotcrete before pumping, wet shotcrete is directly poured into concrete mold. According to the Chinese Standard "Test method for fiber reinforced concrete" (CECS13:2009) and "Concrete quality control standard" (GB 50164-2011), the curing and mechanical tests of specimens were carried out. After 1 day curing in a standard curing chamber with temperature of $20 \pm 2{ }^{\circ} \mathrm{C}$ and $95 \%$ relative humidity, specimens were demolded. Then specimens were cured at standard condition to 28 days. Those specimens were prepared for the measurement of mechanical properties of shotcrete, the methodology is shown in Figure $1 \mathrm{c}, \mathrm{d}$. The $28 \mathrm{~d}$ compressive strength varied between 20.3 (FI29) and 42.6MPa (SF15), while the $28 \mathrm{~d}$ splitting strength varied between 3.6 (SR70) and 5.2 MPa (FI12).

\subsection{Pumpability and Shootability Tests}

Based on the pumping and spraying tests of fresh concrete, the relationship between rheological properties and workability (pumpability and injectability) was studied. SPB7 wet spraying machine was used in the test. The length of the pipe is $25 \mathrm{~m}$, the wind pressure is $0.6 \mathrm{MPa}$, the spray distance is $1 \mathrm{~m}$, and the spray angle is 70-90 degrees. Figure 2 shows the experimental layout. The pressure sensor was installed in different positions. The pressure drop represents pumpability, and the build-up thickness represents shootability [32,48]. The pressure drop $(\Delta \mathrm{P})$ was calculated from the measured pressure value. The measurement way of build-thickness after shotcreting is shown in Figure 2. Lower pressure drop means better pumping performance; thicker build-up thickness means better shootability, and vice versa.

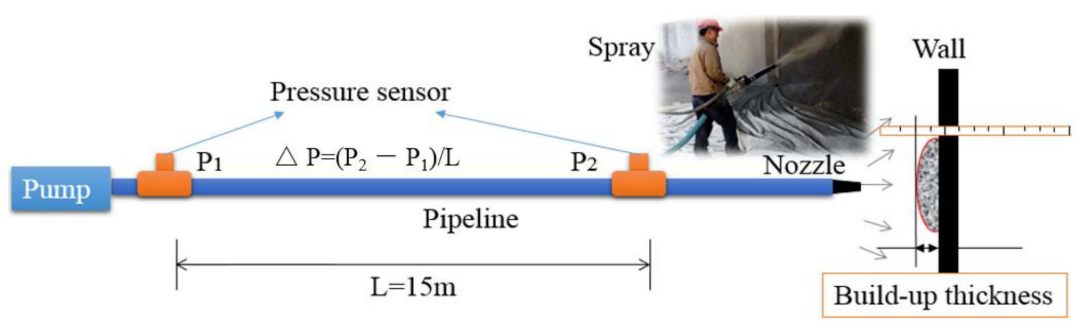

Figure 2. Pumping and shotcreting tests of fresh concrete.

\section{Results and Discussion}

The experimental results of pressure drop and build-up thickness are shown in Table 3. 
Table 3. Results of pumpability and shootability tests of fresh concrete.

\begin{tabular}{cccccc}
\hline No. & $\begin{array}{c}\text { Pressure Drop } \\
\mathbf{( M P a / m )}\end{array}$ & $\begin{array}{c}\text { Build-Up } \\
\text { Thickness } \\
\mathbf{( m m )}\end{array}$ & No. & $\begin{array}{c}\text { Pressure Drop } \\
\mathbf{( M P a / m})\end{array}$ & $\begin{array}{c}\text { Build-up } \\
\text { Thickness } \\
(\mathbf{m m})\end{array}$ \\
\hline WC45 & 0.09 & $170 \pm 20$ & AE0.06\% & 0.03 & $130 \pm 20$ \\
WC50 & 0.08 & $160 \pm 20$ & WR0.3\% & 0.04 & $160 \pm 20$ \\
WC55 & 0.04 & $140 \pm 20$ & WR0.6\% & 0.04 & $150 \pm 20$ \\
WC60 & 0.03 & $130 \pm 20$ & WR0.9\% & 0.03 & $150 \pm 20$ \\
SR50 & 0.07 & $170+20$ & WR1.2\% & 0.03 & $130 \pm 20$ \\
SR60 & 0.05 & $180+20$ & SF5\% & 0.07 & $170 \pm 20$ \\
SR70 & 0.09 & $160 \pm 20$ & SF10\% & 0.08 & $170 \pm 20$ \\
FI6 & 0.08 & $190 \pm 20$ & SF15\% & 0.10 & $190 \pm 20$ \\
FI12 & 0.07 & $190 \pm 20$ & FA5\% & 0.05 & $180 \pm 20$ \\
FI29 & 0.06 & $190 \pm 20$ & FA10\% & 0.04 & $170 \pm 20$ \\
AE0.02\% & 0.05 & $150 \pm 20$ & FA15\% & 0.03 & $160 \pm 20$ \\
AE0.04\% & 0.04 & $130 \pm 20$ & & & \\
\hline
\end{tabular}

\subsection{Influence of Various Factors on Rheology and Air Content of Fresh Wet Shotcrete}

\subsubsection{Effect of Water to Binder Ratio (WC)}

Figure 3 describes the effect of WC on the properties of fresh wet shotcrete. When WC increases from 0.45 to 0.60 , the slump and air content increase, while the rheological parameters (relative yield stress and viscosity) decrease. It can be explained that the larger the $\mathrm{WC}$, the more the free water content in the fresh wet shotcrete, the thicker the outer paste coating of the particles, the larger the spacing between particles, and the bigger the fluidity. In addition, fresh concrete with higher fluidity creates more opportunities for the introduction of air bubbles into the concrete mixture [49]. On the contrary, these bubbles act as "ball effect" to improve the fluidity of fresh wet shotcrete. This schematic diagram is shown in Figure 4. These trends are similar to Yun's report [35], where they measured rheological properties using an IBB rheometer with an H-shaped impeller. The internal structure of the two rheometers is different, such as the shape of the rotor, rotation speed, the size of the rheometer and the distance between the inner and outer rotors. Hence, the relative rheological values measured in the two studies are different. However, the rheological parameters obtained in this study also provide meaningful practical knowledge for guiding the mix proportion of wet shotcrete.

It can be seen from Table 3 that with the increase of WC, the pressure drop decreases, i.e., smaller rheological parameters (yield stress and plastic viscosity) help to improve the pumping performance of fresh concrete. However, the high WC reduces the build-up thickness of concrete, and the shootability of fresh concrete with good pumping performance is poor. The author [35] also pointed out that high WC might be beneficial to pumping performance, but low viscosity and low yield stress might reduce the thickness of the build-up layer. From another point of view, Pfeuffer et al. [50] pointed out that based on the assumption of better aggregate embedding, the viscosity and yield stress of shotcrete need to be lower to minimize the rebound rate. As shown in Figure 5, the wet shotcrete with low fluidity has a strong cohesive force, which increases the accumulation thickness $h_{1}$. At the same time, we redefine $F_{1}$ as the force that prevents particles from entering the shotcrete matrix, because the $F_{1}$ is greater than the incident force $F_{2}$, it may cause certain rebound. On the contrary, wet shotcrete with high fluidity provides convenience for aggregate embedding and reduces rebound. However, it is easy to collapse, resulting in a very thin accumulation of $h_{2}$. 

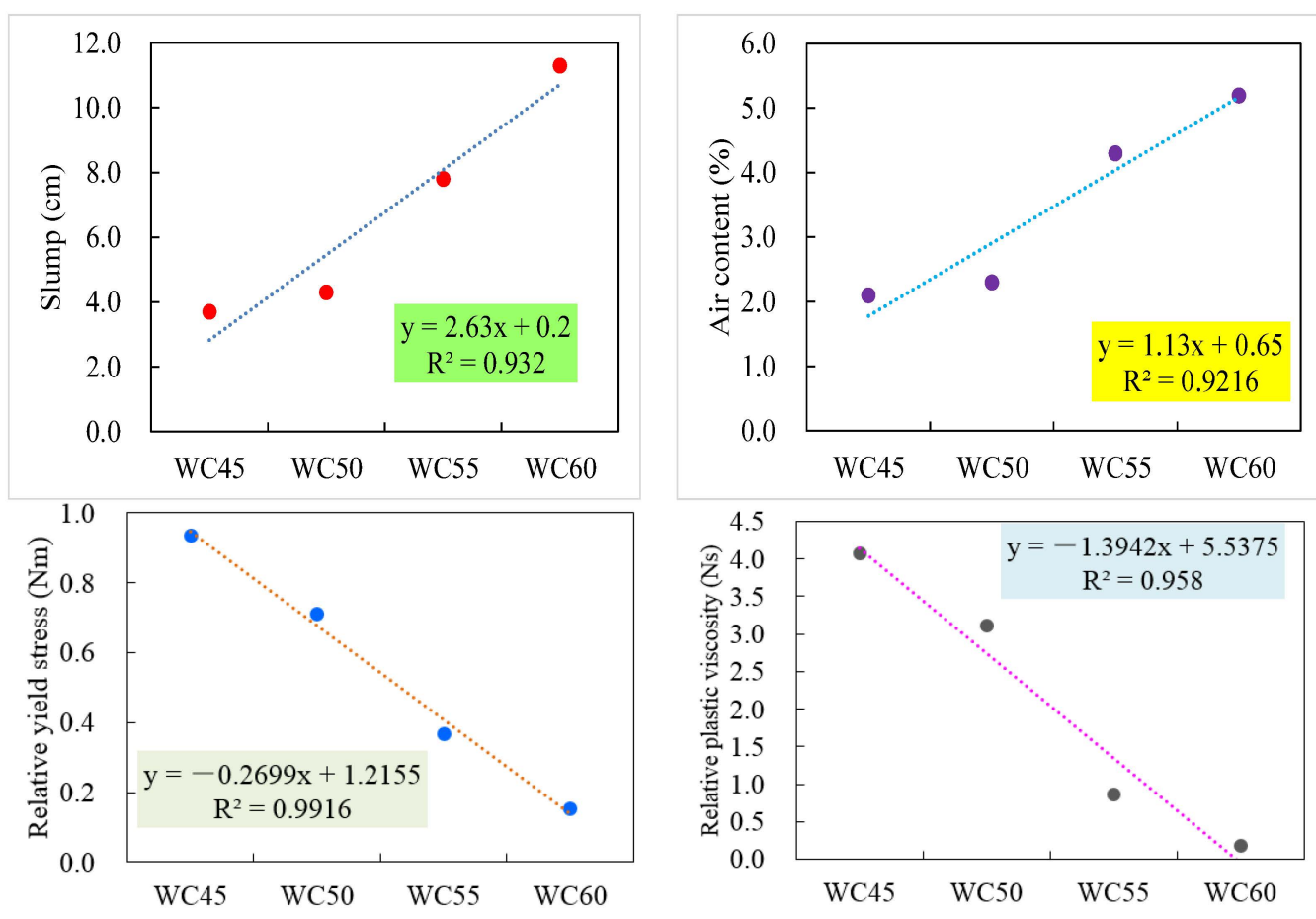

Figure 3. Effect of water-binder ratio on slump, air content, relative yield stress, and viscosity.

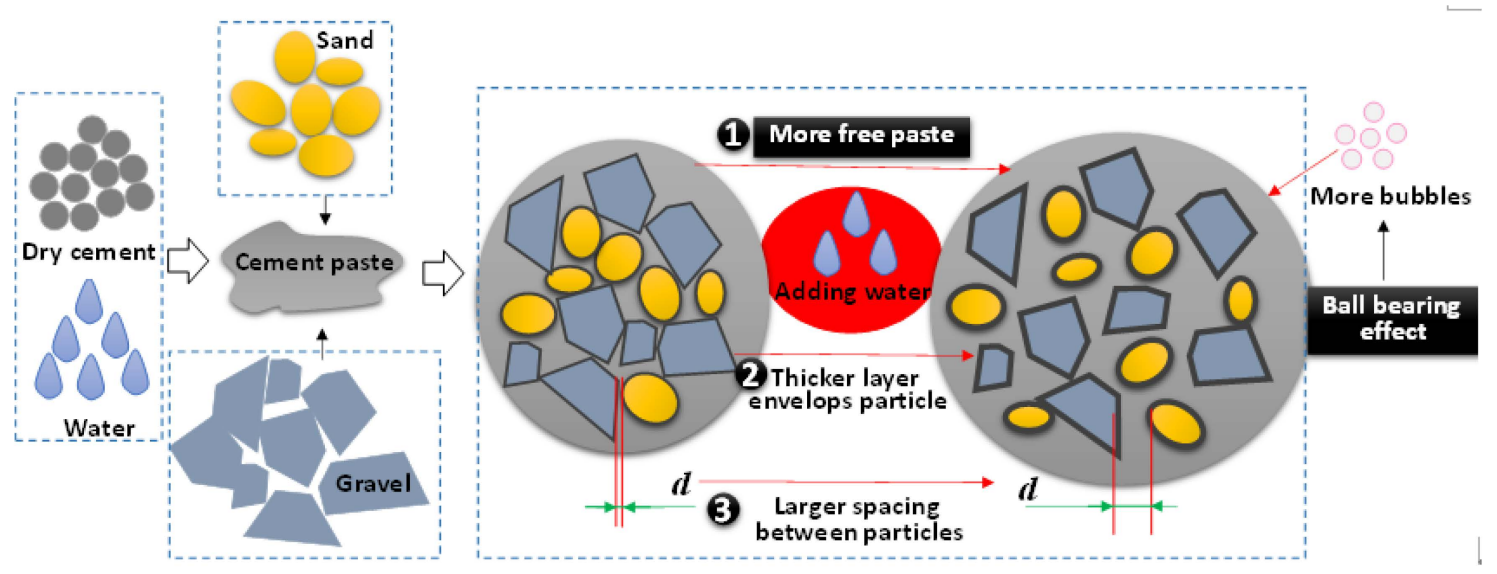

Figure 4. Schematic of the flowability change after increasing water content.

According to the fitting results of the linear relationship in Figure 3, the fitting effect of the four relationships between WC and rheological parameters is good, $\mathrm{R}^{2}$ is more than 0.9 , close to 1 . The linear fitting effect between $\mathrm{WC}$ and yield stress is the best, $\mathrm{R}^{2}=$ 0.9916. The WC vs. air content is the worst, $\mathrm{R}^{2}=0.9216$. The bubble system in fresh wet shotcrete becomes unstable due to high WC, which may be the reason for poor fitting effect of air content. 


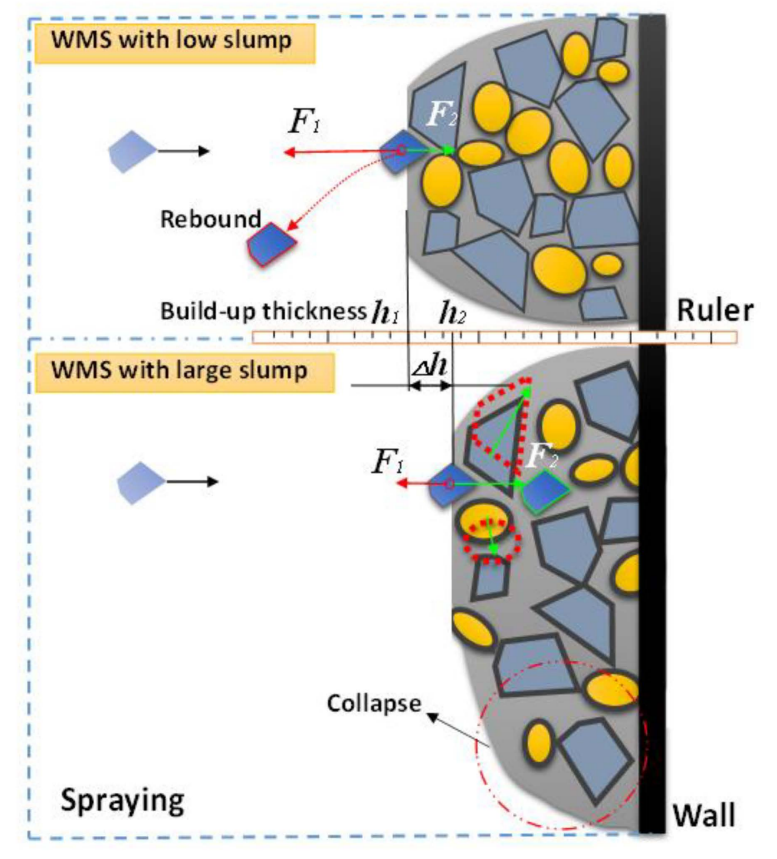

Figure 5. Shootability compression between low slump and large slump.

\subsubsection{Effect of Sand Ratio}

Figure 6 shows that with the increase of SR, the slump decreases gradually, while the air content increases. Within the range of $50-60 \%$ of SR, the relative yield stress increases, and the relative viscosity changes slightly with a downward trend. Some researchers [51-53] have reported the same result that increasing strontium increases the yield stress but decreases the plastic viscosity. Westerholm et al. [54] also found that natural fine aggregate has little effect on plastic viscosity.
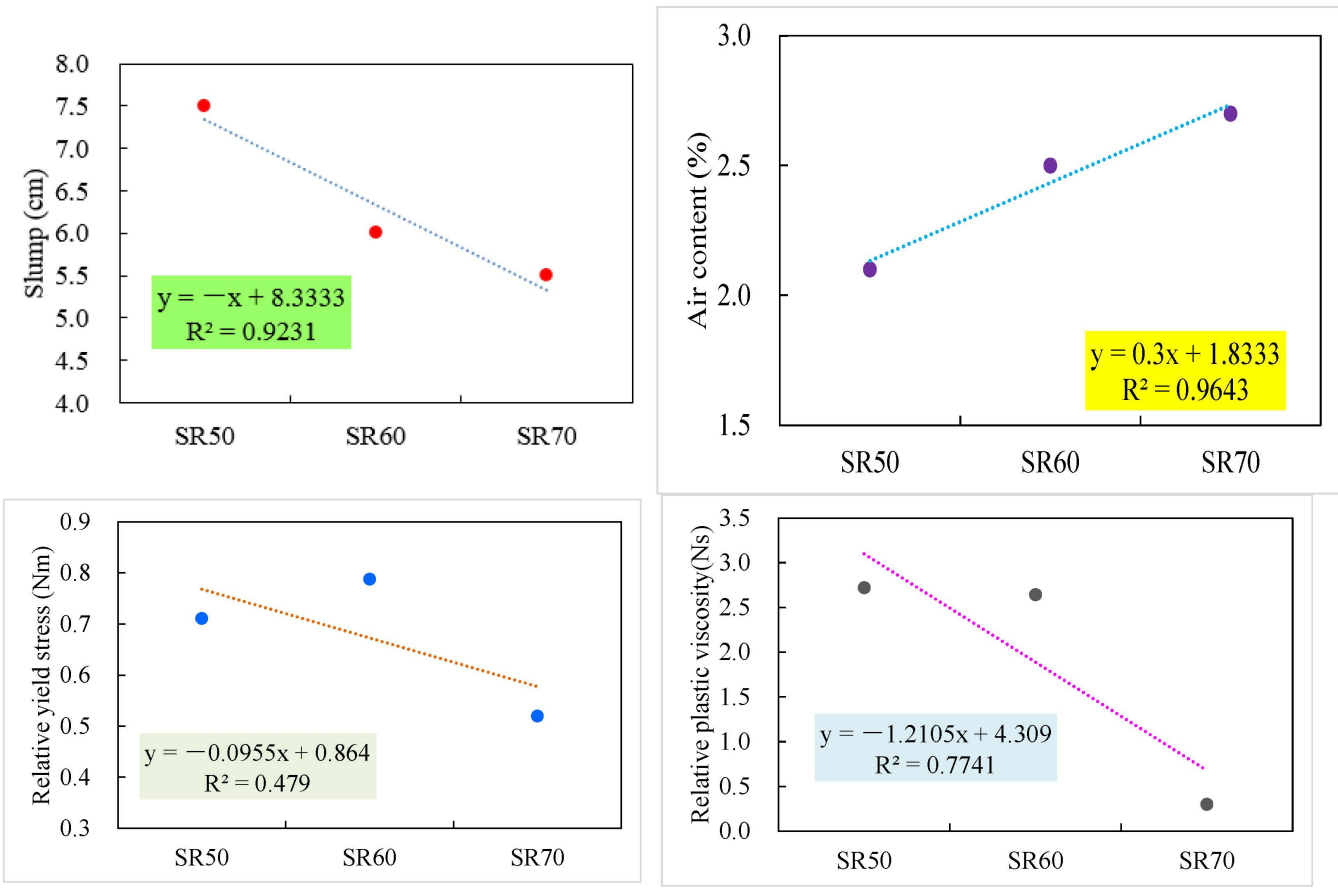

Figure 6. Effect of sand ratio on slump, air content, relative yield stress and viscosity.

The analysis shows that the texture of sand is smoother than that of gravel when "ball effect" is considered. The increase of SR reduces the content of gravel, and more 
sand as a kind of ball can fill the gap between coarse aggregates, resulting in the release of cement paste embedded in the voids and the decrease of inter particle friction. However, if the sand volume fraction is further increased, the total surface area of solid particles will increase, the consumption of cement paste will increase, the yield stress and friction between particles will increase, which will reduce the fluidity of fresh wet shotcrete. The author [55] divides the influence of SR on the fluidity of concrete into two parts: the smaller volume of SR has a negative effect on the fluidity of concrete, because there is no mortar filling the gap in the coarse aggregates; the higher volume SR also reduces the fluidity, because the high specific surface area of fine aggregate consumes too much free paste that lubricates the aggregate particles and the inner wall of the pipe. Therefore, there is a critical SR value, and the positive and negative effects of free paste or ball bearing are balanced. Considering the shootability, the round sand particles are unfavorable to the accumulation thickness. The greater the sand content, the greater the density of shotcrete and the higher the compressive strength.

According to Table 3, SR60 is the best value to obtain both good pumping performance and good shooting performance in the range of SR50 to SR70. Of course, due to the small number of experimental samples in this study, further research is needed to find the accurate critical point. The positive and negative effects of SR on liquidity of wet shotcrete are shown in Figure 7.

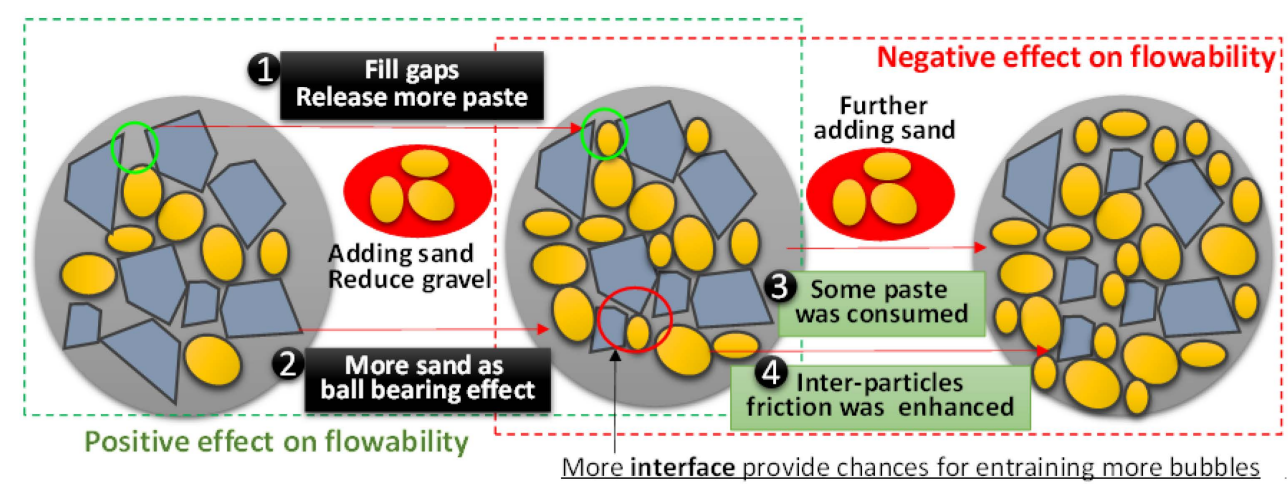

Figure 7. Schematic of the effect of sand ratio (SR) on the flowability.

In terms of air content, adding more fine aggregate will increase the total surface area of solid particles in fresh wet shotcrete, which provides more opportunities for liquid-solid interaction, thus bringing more bubbles [56,57]. It was noted that the mixture labeled "SR70" was mixed with $0.3 \%$ water-reducing agent to ensure good pumping effect. Therefore, when the content of SR is $60-70 \%$, the yield stress and viscosity are reduced by further increasing SR. In addition, the change of SR affects the mix proportion and bulk density. Jiao et al. [58] pointed out that the volume fraction and bulk density of aggregate have obvious influence on the rheological properties of concrete. The bulk density is related to the type, gradation, and size distribution of aggregates. Relevant studies on these aggregate parameters are given in $[51,58,59]$.

According to the linear fitting results in Figure 6, the fitting effect between SR and slump or air content is good, $\mathrm{R}^{2}$ is greater than 0.9. However, the fitting of rheological parameters is poor, the relative yield stress $R^{2}=0.479$, the relative viscosity $R^{2}=0.7741$, which may be due to the introduction of superplasticizer in SR70.

\subsubsection{Effect of Fiber}

Figure 8 shows the relationship between fiber length and rheological properties, and air content. The air content, relative yield stress, and viscosity showed an increasing trend while slump decreases with the increase of fiber length. The results show that the fiber has an adverse effect on the fluidity with high yield stress and high viscosity, which is consistent with the results confirmed by Sivakumar et al. [60]. The reason may be that the 
specific surface area of long fiber is large, which can consume a part of free cement paste, and the friction between particles and aggregate increases with the increase of fiber length. Tabatabaian et al. [20] indicated the existence of fiber hinders the flow of cement paste. In the same way, increasing the total surface of the solid after mixing the long fibers will cause more bubbles to be entrained in, resulting in a higher air content in the "FI29 mm" mixing ratio. The schematic diagram of FI affecting fresh shotcrete characteristics is shown in Figure 9.
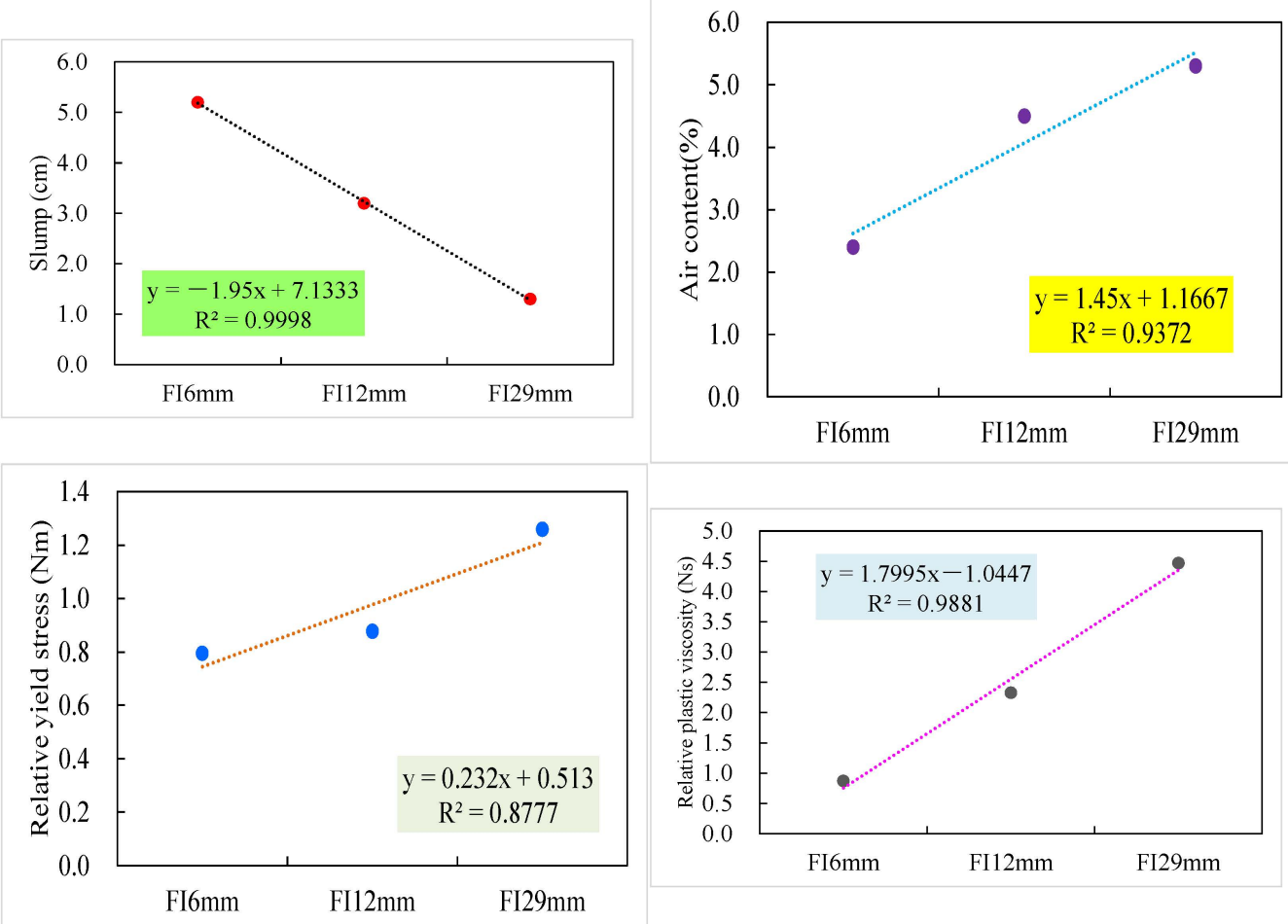

Figure 8. Effect of fiber on slump, air content, relative yield stress, and viscosity.

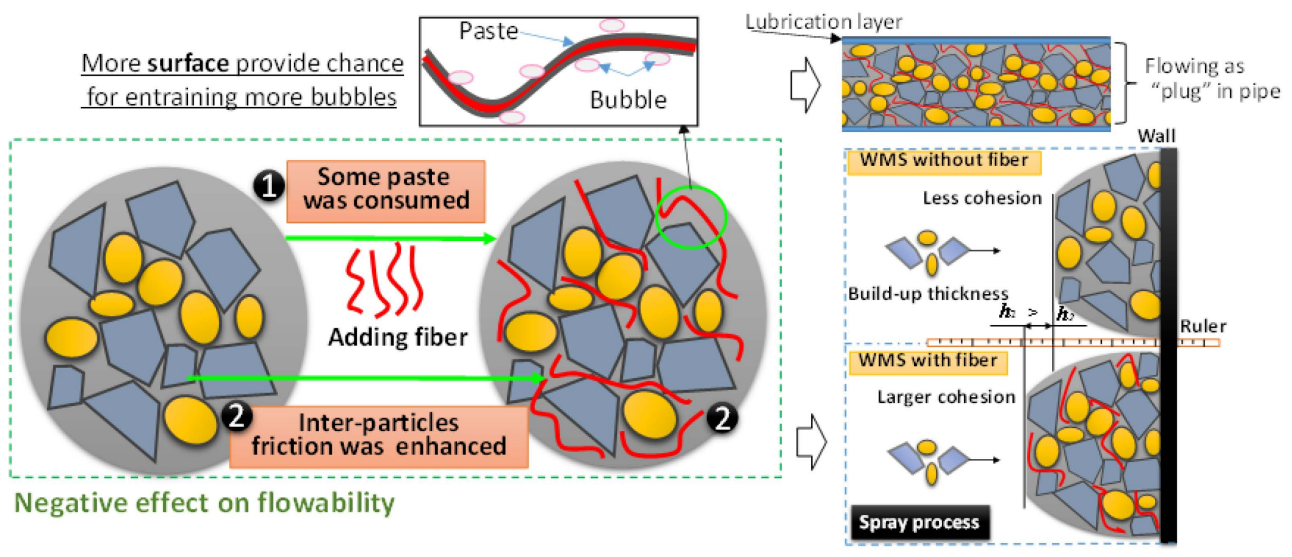

Figure 9. Schematic of fiber (FI) affecting the flowability, shootability, and air content.

Combined with the experimental results of pumpability and shootability in Table 3, longer fibers help to reduce pressure drop and increase build-up thickness. In addition, it is determined that the addition of fibers can improve the shootability by increasing the stacking thickness [35]. In report [32], the authors point out that low slump does not mean low pumpability. Adding fiber into fresh concrete can improve the bond strength of fresh concrete and reduce the segregation during pumping. However, Yun et al. [35] considered that the mixed fiber has an adverse effect on the pumpability of fresh wet 
shotcrete (reducing slump and increasing yield stress). Different results may be related to the lubrication layer in the pipeline. If the lubricating layer has been formed, the low slump concrete will flow in the form of "plug", and the friction resistance is small.

According to the linear fitting results in Figure 8, the fitting effect of fiber and slump is the best, $R^{2}=0.9998$, and the fitting effect of yield stress is the worst, $R^{2}=0.8777$. The prediction results of the influence of fiber on rheological properties and air content may be used in practice.

\subsubsection{Effect of Air-Entraining Agent}

Figure 10 shows that with the increase of air-entraining agent content, the air content slump increase, while the relative yield stress and viscosity decrease. The results show that adding more air-entraining agent in fresh wet shotcrete will produce a lot of bubbles, which plays a role of "ball effect". These entrained bubbles play a key role in lubricating aggregate and further affect the consistency of fresh wet shotcrete. The fluidity of wet shotcrete is improved, the slump is increased, and the yield stress and viscosity are reduced. Similarly, Yun et al. [35] has been pointed out that the torque viscosity decreases significantly with the increase of air content. However, in an earlier study [61], the author showed that there was a critical air content of $5 \%$, before which both flow resistance and torque viscosity decreased; after this point, the two rheological parameters tended to be stable. In our study, when $0.02 \%$ air-entraining agent is mixed, the air content reaches $13.5 \%$, far exceeding the critical value of $5 \%$. The corresponding criterion in reference [61] is invalid. This difference can be explained by two factors: one is the application of different types of test equipment or the type of fresh concrete (ordinary concrete with aggregate size greater than $30 \mathrm{~mm}$ and shotcrete with maximum particle size of $10 \mathrm{~mm}$ ); the other can be found in [58]. The author [58] proposed that since bubbles are attracted to the cement particles to form a bubble bridge, which increases the bond strength between cement particles (similar to flocculated particles), the entrained bubbles may lead to an increase in yield stress. Once the bubble bridge breaks under strong shear, some of the retained paste is released, apparently acting as a lubricant, as shown in Figure 11. We can conclude that bubbles have two functions: binding and lubrication. Both are related to shear strength and aggregate parameters. Therefore, some reports [62,63] show that the yield stress increases or remains stable with increasing air content.
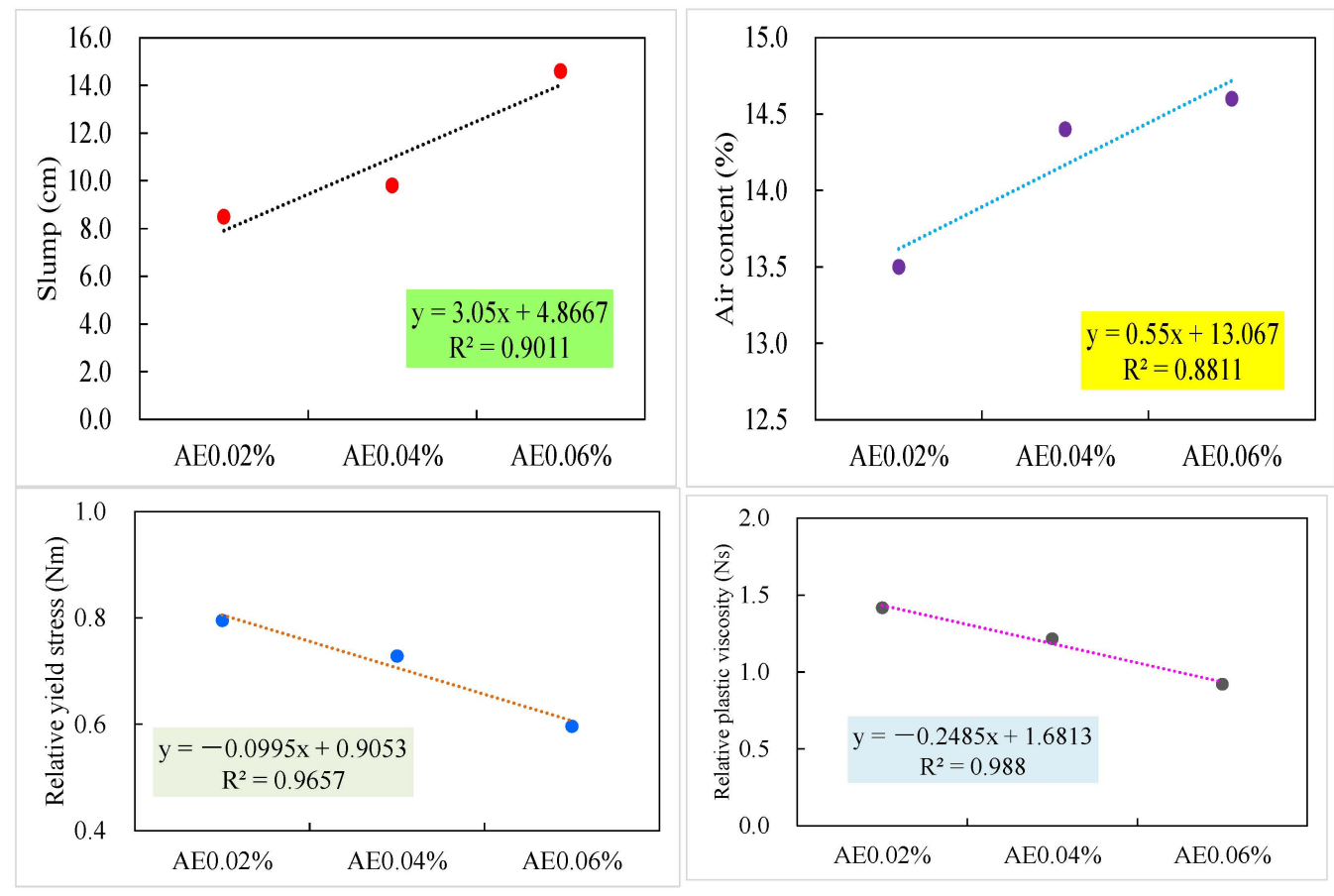

Figure 10. Effect of air-entraining agent on slump, air content, relative yield stress, and viscosity. 


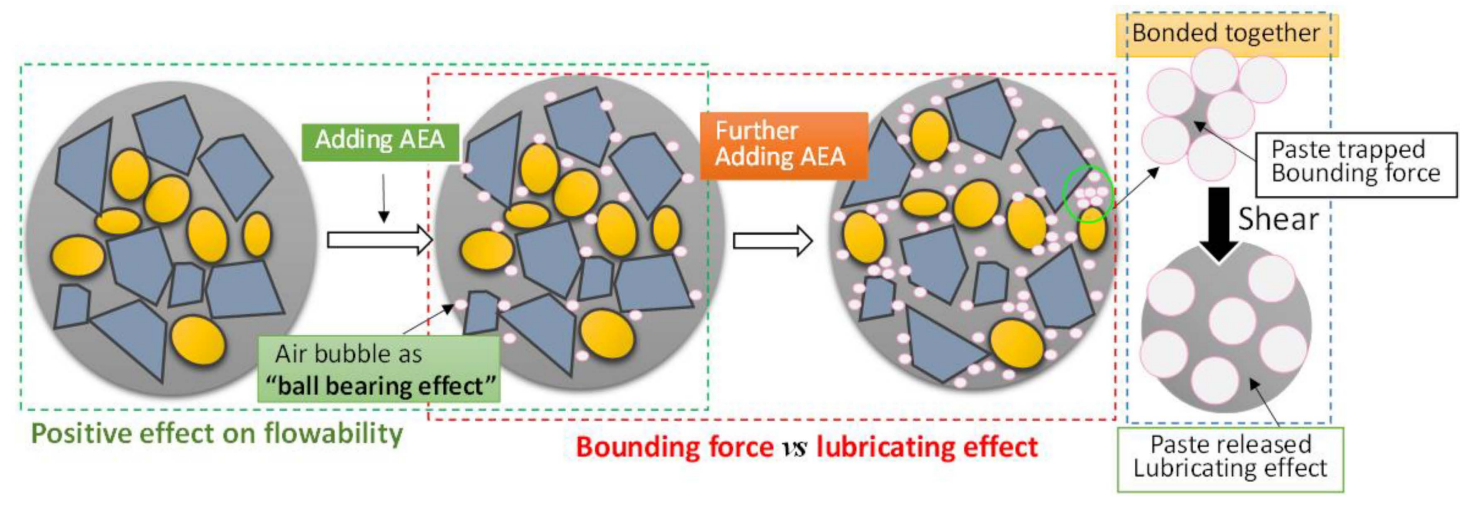

Figure 11. Schematic of the effect of air bubble on flowability of WET SHOTCRETE.

In our study, adding air-entraining agent can improve the pumping performance of concrete in Table 3. Therefore, we infer that in this measurement process, the lubrication effect of bubbles is significantly greater than that of adhesion, with the range of $\mathrm{AE} 0.02 \%-\mathrm{AE} 0.06 \%$. Due to the spraying process of fresh wet shotcrete, bubbles will break and disappear, this kind of fresh concrete has better shotcreting property with good cohesion. Therefore, the air-entraining agent can improve the pumpability and sprayability in a certain range, which is worthy of recommendation in the application of wet concrete.

According to the linear fitting results in Figure 10, the air-entraining agent has a good fitting effect on the rheological parameters, with the relative yield stress $R^{2}=0.9657$ and the relative viscosity $R^{2}=0.988$. Air-entraining agent has the worst fitting effect on air content, which may be the cause of instability of fresh concrete with more bubbles. The prediction results of total rheological properties and air content are ideal.

\subsubsection{Effect of Water Reducer}

Figure 12 shows that the relative yield stress, viscosity, and air content decrease with the increase of water reducer dosage from $0.3 \%$ to $1.2 \%$, while the slump is opposite. Under the same water-binder ratio, the fluidity of fresh concrete is greatly improved when the quality of water-reducing agent is mixed. When $1.2 \%$ water-reducing agent is added, the slump value reaches $15.1 \mathrm{~cm}$, which is much higher than that of wet shotcrete with other admixtures. There was no bleeding or separation during tests. Jiao et al. [58] indicated that the spatial resistance effect of water-reducing agent is one of the reasons for this phenomenon. After adding water reducer, the yield stress and viscosity of fresh concrete decrease significantly. As shown in Figure 13, after adding water reducer, the flocculability of cement particles decreases because water reducer makes cement particles bringing same charge. In addition, the efficiency of water reducer also depends on the adsorption of water-reducing agent molecules to cement particles and the repulsion force produced by adsorption molecules. Kwan et al. [64] found that the addition of waterreducing agent increases the effective layer thickness of cement particles covered by paste. The increase of the bridging distance between particles reduces the maximum attraction between particles. Perrot et al. [65] concluded that with the increase of water-reducing agent dosage, the average surface spacing increases, and the colloidal interaction and flocculation degree between particles are reduced, thus reducing the rheological parameters of fresh wet shotcrete. 

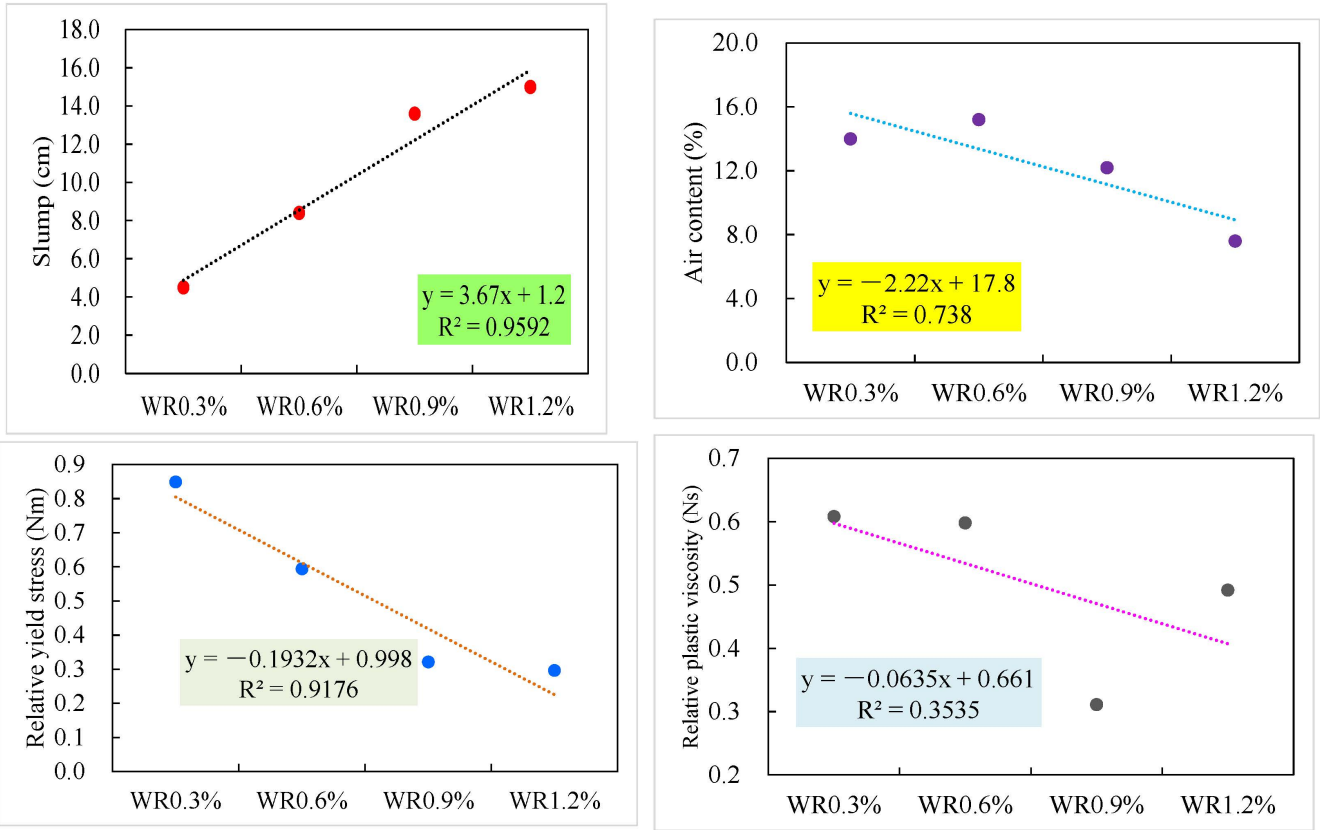

Figure 12. Effect of water reducer on slump, air content, relative yield stress, and viscosity.

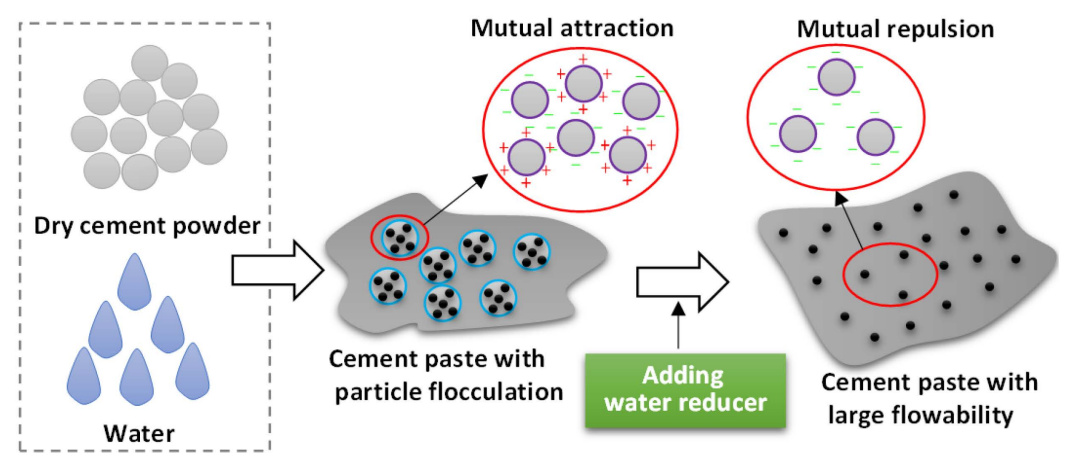

Figure 13. Mechanism of water reducer affecting cement paste.

When WR exceeds $0.9 \%$, the relative yield stress decreases slowly, the plastic viscosity increases inversely. It might be explained that there is a critical saturation point for the efficiency of superplasticizer. Beyond this point, more superplasticizers will increase the viscosity of the liquid. Compared with other admixtures (except air-entraining agent), the air content of wet shotcrete with water-reducing agent is relatively high, with an average of $12.25 \%$. The analysis shows that the water reducer contains a certain amount of surfactant and thus introduces some bubbles. If the superplasticizer is continued to be added, excessive water reducer will increase the viscosity of the liquid and hinder the generation of bubbles, which will lead to the decrease of air content.

According to the fitting results in Figure 12, the slope of the linear equation represents the rate of increase or decrease. The decrease of relative yield stress is greater than that of relative plastic viscosity. The results show that superplasticizer has good fitting effect on slump and relative yield stress, $R^{2}=0.9592$ and $R^{2}=0.9176$, respectively, which can be used to predict the changes of these two properties.

Table 3 shows that adding more superplasticizers can reduce the stacking thickness. It is pointed out that although water-reducing agent is almost used in modern pouring concrete due to its economic and technical benefits, the application of water-reducing agent is not conducive to improving the shootability of concrete. It is suggested that when premixing water-reducing agent in front of pump, additives such as viscosity agent or accelerator should be added at the same time to restore or improve its shooting performance. 


\subsubsection{Effect of Fly Ash}

As shown in Figure 14, with the increase of fly ash content from $5 \%$ to $15 \%$, the slump value increases more than twice, and the relative yield stress and viscosity decrease by about $50 \%$. Generally speaking, the fluidity of shotcrete can be significantly improved by adding fly ash. Similar results with positive effect of fly ash on fluidity are also reported in references [66,67]. According to the pumping test in Table 3, adding fly ash can improve the pumping performance, reduce the pressure drop, but reduce the sprayability, and the build-up thickness is small. This phenomenon may also be attributed to the "ball effect" and "free paste effect". The content of $\mathrm{CaO}$ in the fly ash used in this test is less than $10 \%$, which belongs to Class F fly ash. The fly ash particles have spherical geometry and smooth surface (Figure 15 [68]) to enhance the "ball bearing effect" by reducing friction and promoting sliding between angular particles. Vance et al. [69] pointed out that this effect will be amplified with the widening of fly ash particle size distribution. Fly ash, as a fine particle with a particle size of $0.4-100 \mu \mathrm{m}$, fills the gap between larger particles, and extrudes the original water in the gap to increase the volume of free paste, which is called free paste effect. The use of fly ash instead of cement reduces the cement concentration and further reduces the flocculation of cement particles. In addition, because the specific gravity of fly ash particles is lower than that of cement particles, the volume of paste will increase when fly ash replaces cement with the same quality. Therefore, more free paste volume as lubricant increases the fluidity of wet shotcrete, which is called dilution effect. The influence of fly ash on the fluidity of fresh concrete is shown in Figure 15.

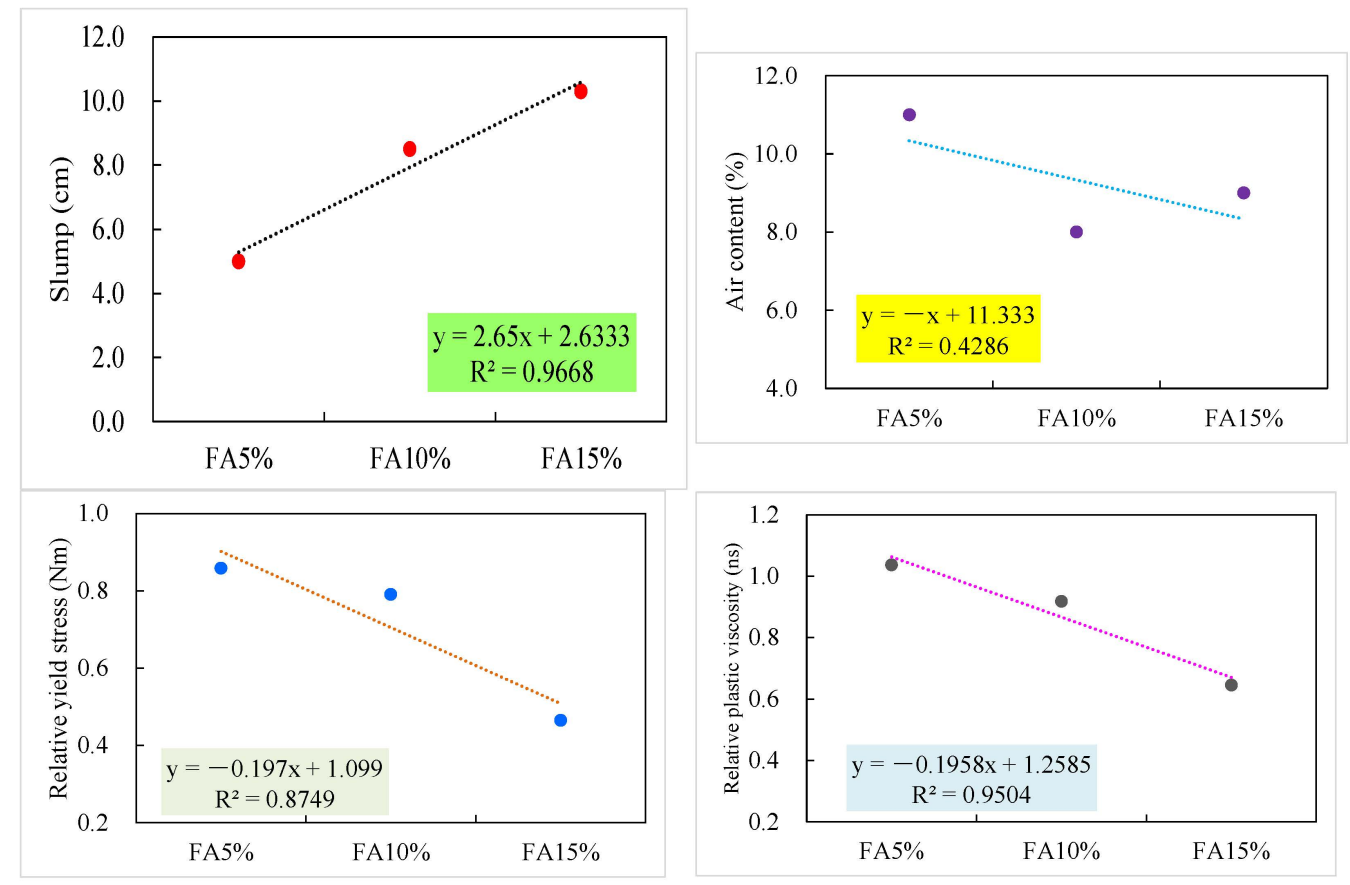

Figure 14. Effect of fly ash on slump, air content, relative yield stress, and viscosity.

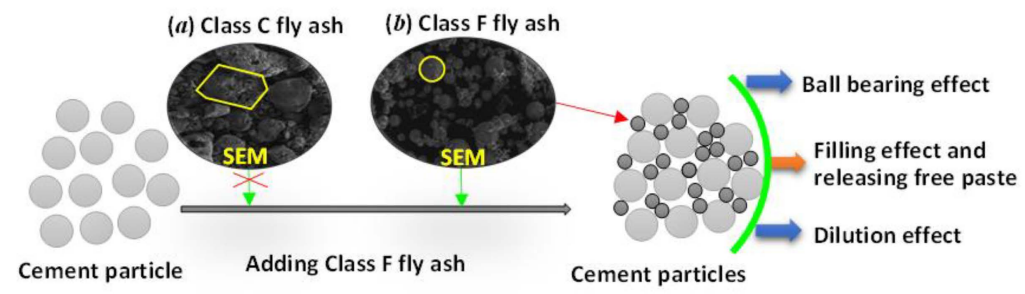

Figure 15. Effect of fly ash on the flowability of fresh wet shotcrete. 
This does not mean that the more fly ash is, the higher the fluidity of the new concrete. Laskar et al. [66] found that when a higher content of fly ash is mixed, the yield stress increases. This is also related to the types of fly ash, for example, the Class $\mathrm{C}$ fly ash in Figure 15a is irregular and porous, and the lubrication is weak. $\mathrm{CaO}$ in Class $\mathrm{C}$ fly ash is more, and its viscosity is relatively higher after hydration.

According to the fitting results in Figure 14, the fitting effect of fly ash on slump and relative plastic viscosity is good, $R^{2}=0.9668, R^{2}=0.9504$ respectively, with good prediction effect. With the increase of fly ash content, the air content changes greatly, leading to the bad fitting effect of fly ash and air content, $\mathrm{R}^{2}$ is less than 0.5 .

\subsubsection{Effect of Silica Fume}

Figure 16 shows that the addition of silica fume reduces the fluidity of fresh wet shotcrete, reduces the slump, and increases the relative yield stress and viscosity. In terms of filling effect and ball bearing effect, the average particle size of silica fume (about $0.1-$ $0.3 \mu \mathrm{m})$ is smaller than that of cement $(30-60 \mu \mathrm{m})$. Jiao et al. [58] pointed out that the particles below $0.1 \mu \mathrm{m}$ account for more than $80 \%$ in silica fume, and the particle geometry is circular. These conditions provide the possibility of filling silicon powder particles between larger particle gaps as ball bearings. In this normal case, the free paste effect enhanced by particle filling effect will improve the fluidity of fresh wet shotcrete. This mechanism is similar to that of fly ash. However, due to the high silica content (85-96\%), silica fume has high chemical activity. It participates in the hydration process of cement and increases the consistency of cement and the friction between particles. After adding silica fume, the fluidity of fresh wet shotcrete decreases because the effect of free paste is less than the effect of flocculation. In this study, the relative yield stress and viscosity increased after adding 5\% silica fume. This result is similar to previous work [35], which reported that the flow resistance of fresh concrete increases with silica fume content greater than $7 \%$.

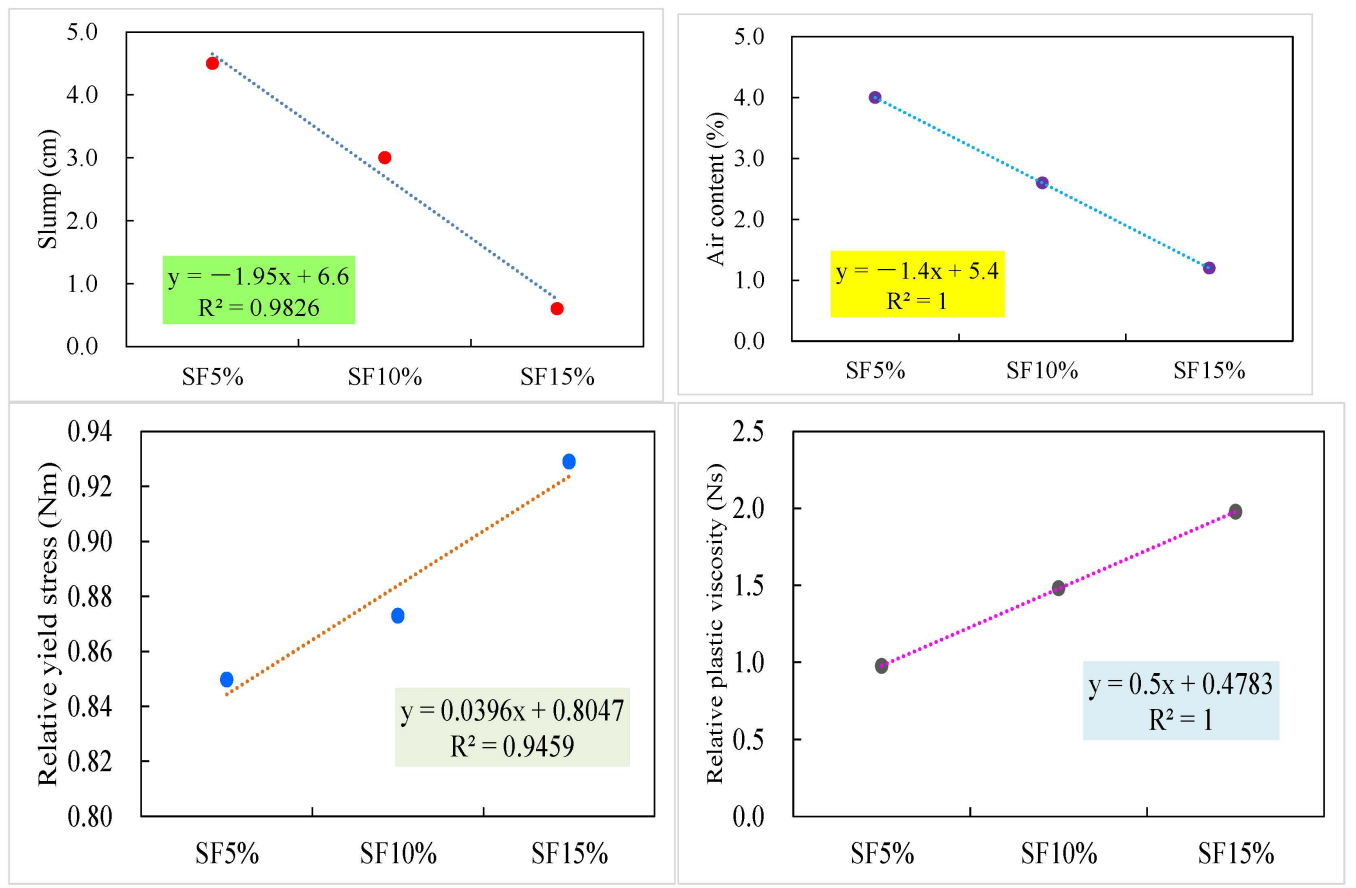

Figure 16. Effect of silica fume on slump, air content, relative yield stress, and viscosity.

Considering that silica fume reduces the fluidity of wet shotcrete, superplasticizer was added into the mixture to ensure good pumping performance. It can be seen from Figure 16 that the effect of water-reducing agent on wet shotcrete with silica fume is not obvious, because after adding water reducer, the slump cannot reach a large slump, and 
the slump value is less than $5 \mathrm{~cm}$. It has been reported in the previous literature $[35,38,66]$ that the high specific surface area of silica fume adsorbs water-reducing agent molecules and reduces the water-reducing effect. Air content decreases with the increase of silica fume content. This may be caused by the decrease of water because the high fineness and high chemical activity of silica fume increase the demand for water. Under the same water content, adding more silica fume consumes too much water and reduces the chance of introducing bubbles into fresh shotcrete.

As shown in Table 3, the increase of yield stress and viscosity is beneficial to buildup thickness. Due to the additional flocculation of silica fume, the bond strength of concrete mixture on surface sprayed is enhanced, and the segregation and bleeding in the pumping process are reduced. Beauprep [31] gave a similar result, i.e., when 10-15\% silica fume is added to wet shotcrete, silica fume has a positive effect on both sprayability and pumpability. It can be seen from the fitting results in Figure 16 that the silica fume has a good fitting effect on the air content and rheological parameters.

We try to illustrate the influence of various factors on shotcrete performance through pictures, such as Figures 4,5 and 7 , etc. It should be noted that only three or four factor levels are selected in this study. Figures 3, 6, 8, 10,12,14 and 16 only adopt linear fitting method, but in fact, exponential fitting equation may be more suitable for the change trend of some influencing factors, such as w/c ration. Because the test data of each factor is relatively small and the fitting variance is small, all the fitting patterns in those figures are only used as a reference. In future studies, we will increase the number of test samples.

\subsection{Difference Analysis of Various Impact Factors}

According to the experimental data of rheological parameters and air content, the influence degree of rheological properties and air content are analyzed within the range of variables set in this test. To eliminate the influence of different factors on the measurement scale, the "coefficient of variation" analysis method is adopted [70,71]. Calculation steps: (1) calculate the average value and standard deviation of the same project affected by a different degree of influencing factors; (2) divide the standard deviation by the average value, and the result is "coefficient of variation"; (3) plot the coefficient of variation into a graph. The corresponding results are shown in Figures 17-20. The greater the coefficient of variation, the greater the influence of each factor on wet shotcrete.

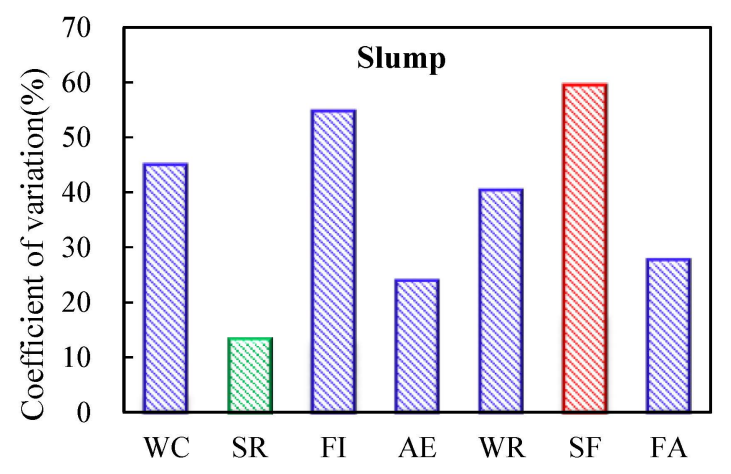

Figure 17. Difference analysis of factors on slump. 


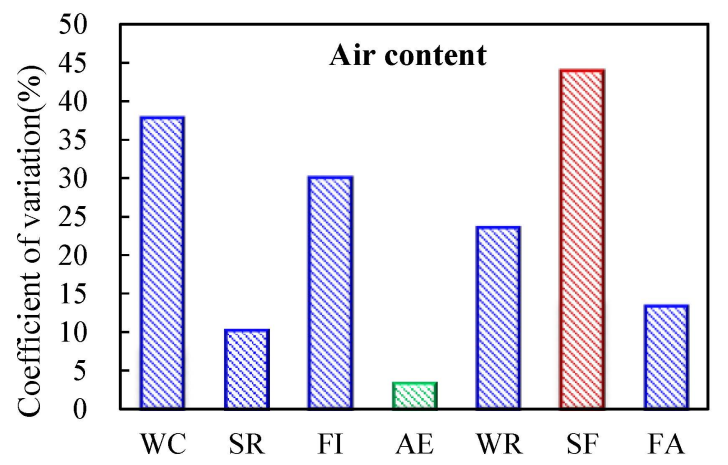

Figure 18. Difference analysis of factors on air content.

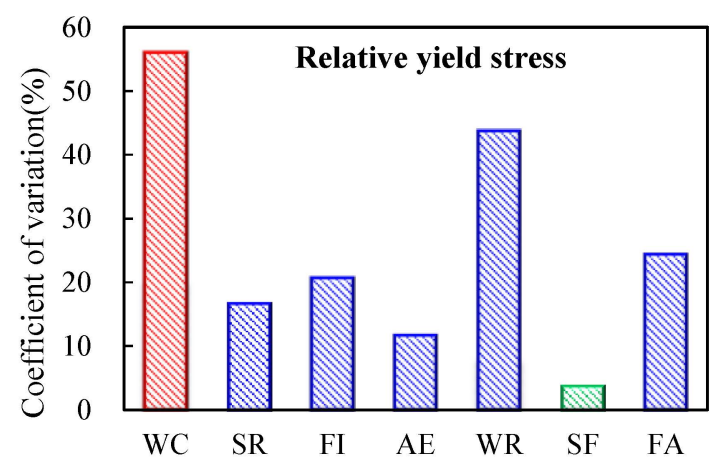

Figure 19. Difference analysis of factors on yield stress.

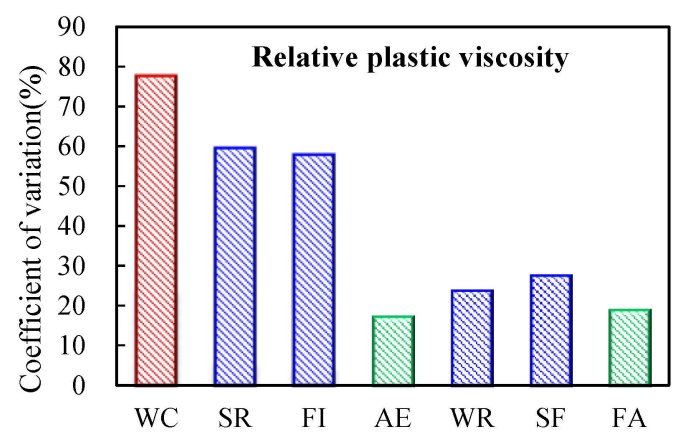

Figure 20. Difference analysis on viscosity.

It can be seen from Figures 17 and 18 that silica fume has the greatest influence on the slump and air content within a given range of variables, with variation coefficients of $60.1 \%$ and $45.2 \%$ respectively. Sand ratio has the least effect on slump (13.2\%) while air-entraining agent has the least effect on gas content (4.3\%). In addition, water-binder ratio (WC), fiber (FI) and water-reducing agent (WR) have great influence on slump and air content.

It can be seen from Figures 19 and 20 that the water-binder ratio (WC) has the greatest effect on the relative yield stress and plastic viscosity within a given range of variables. Secondly, for yield stress, water reducer (WR) and fly ash (FA) have great influence on it, silica fume (SF) has the least influence; for plastic viscosity, sand ratio (SR) and fiber (FI) have great influence on it, while air-entraining agent (AE) or fly ash (FA) has relatively small effect.

In fact, the coefficient of variation of influencing factors is related to the range of variables set in this experiment, and related to the special working performance of the same influencing factor. For example, fly ash has "ball effect" and silica fume has "filling effect". It is hoped that the analysis of the coefficient of variation can provide a useful reference for the mix proportion design of wet shotcrete. 
3.3. Comparison of the Effects of Fly Ash, Silica Fume on Rheological Properties and Air Content

To understand deeply the effects of silica fume or fly ash on the properties of fresh wet shotcrete, the comparison between these two and other admixtures were analyzed.

According to the comparative analysis of Figure 21, it can be concluded that:

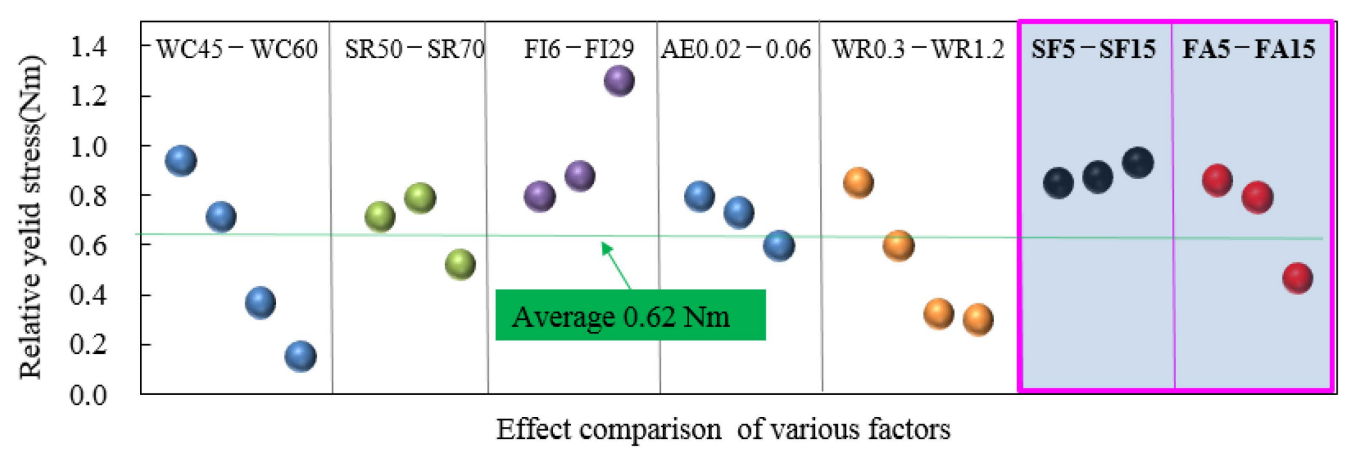

(a) Effect on relative yield stress

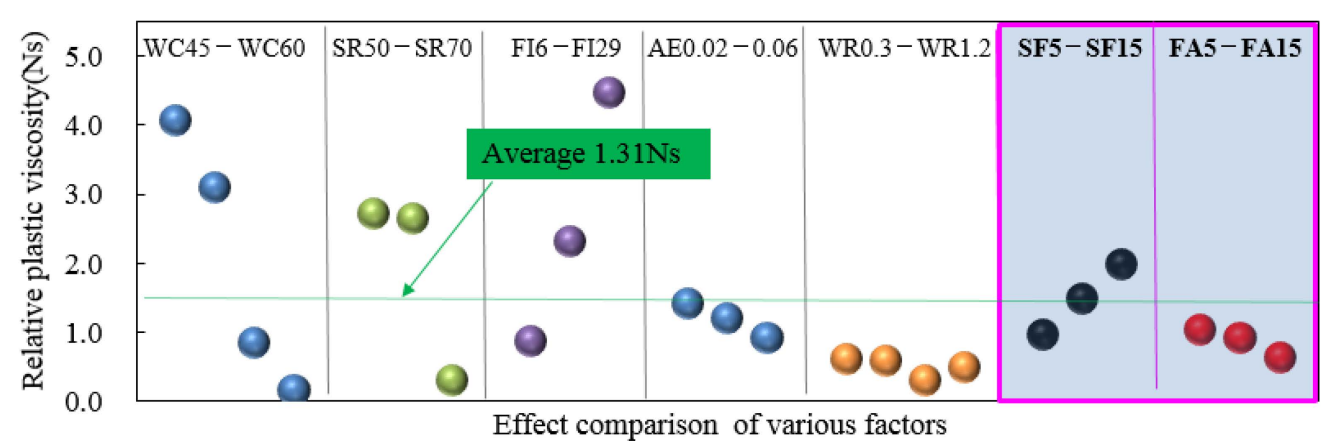

(b) Effect on relative plastic viscosity

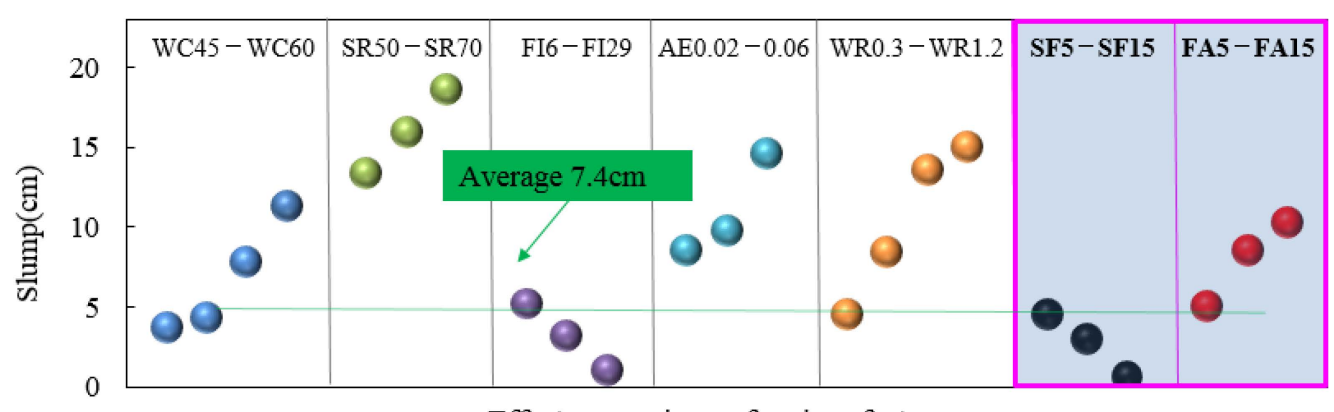

Effect comparison of various factors

(c) Effect on slump

Figure 21. Cont. 


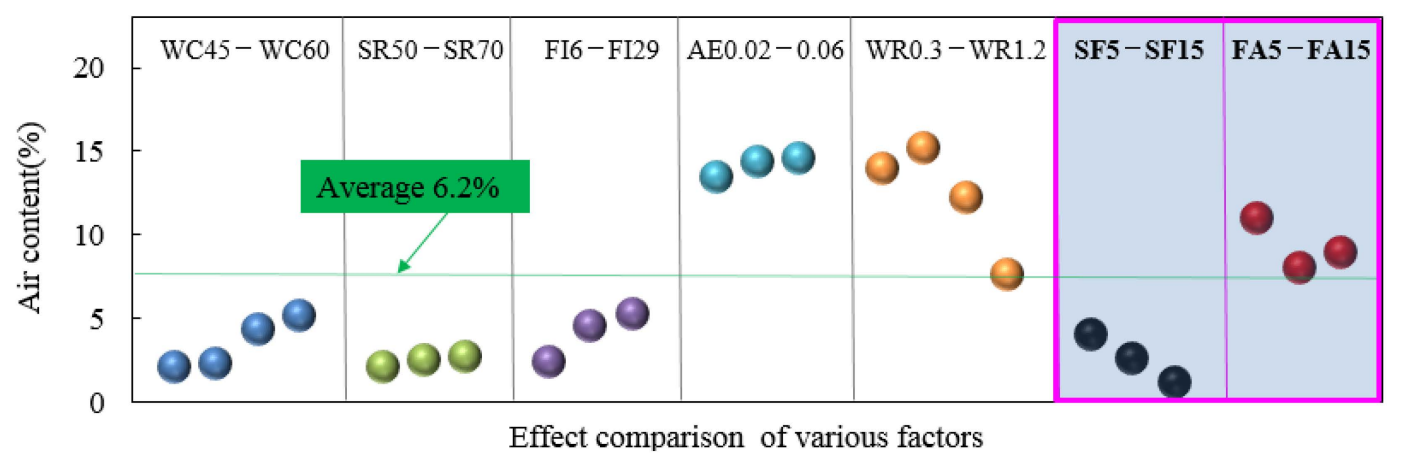

(d) Effect on air content

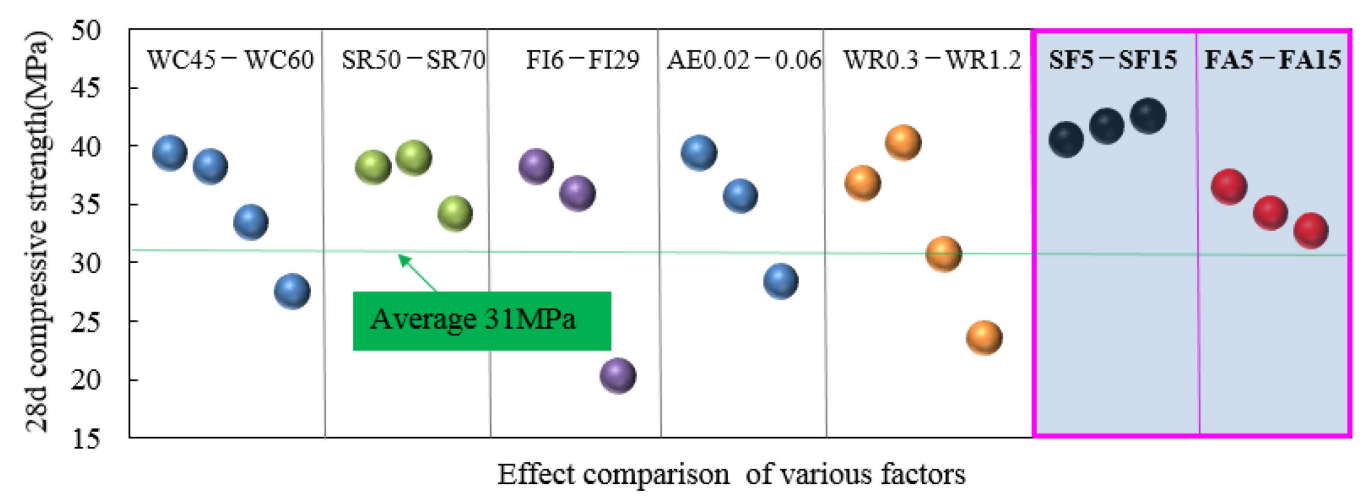

(e) Effect on 28d compressive strength

Figure 21. Comparative analysis of influence between fly ash, silica fume, and other factors.

In the aspect of relative yield stress, the effect of silica fume (SF) on the yield stress of wet shotcrete is similar to that of low water-binder ratio (WC), medium sand ratio (SR) and fiber (FI), almost exceeding the average value of $0.745 \mathrm{Nm}$. Fly ash (FA) and air-entraining agent $(\mathrm{AE})$ have the same effect, showing a downward trend. It can be seen from the data in Table 3 that the high yield stress is beneficial to the shoot property, and the addition of silica fume or a small amount of fly ash can produce a better build-up thickness.

In the aspect of relative plastic viscosity, the influence degree of fly ash on plastic viscosity is similar to that of air-entraining agent, which is lower than the average value of 1.31 Ns. The similar effect can be produced by low dosage of water-reducing agent, high water-binder ratio, or high sand ratio. When the dosage of silica fume is $5-15 \%$, the plastic viscosity is little affected and fluctuates around the average value. For the flow of fresh wet shotcrete in the pipeline, if a lubricating layer is formed on the inner wall of the pipe, the higher viscosity will improve the anti-segregation and anti-bleeding ability of the wet shotcrete containing silica fume, avoid blocking and increase the build-up thickness. However, for shear flow, lower viscosity is beneficial to the pumping performance of fresh wet shotcrete. Therefore, adding fly ash is beneficial to pumping.

In terms of slump: the effect of adding silica fume and fiber in fresh wet shotcrete is similar, and the slump of both is lower than the average value of $7.4 \mathrm{~cm}$. The effect of adding fly ash on slump is similar to that of low air-entraining agent or low water-reducing agent. According to the test of pumpability and shootability, high slump is beneficial to pumping. Fly ash is better than silica fume in pumping process, but the shootability is opposite. It should be noted that the change trend of slump is opposite to that of relative yield stress, which is also reported in $[29,52]$.

In terms of air content, the air content of wet shotcrete mixed with silica fume is lower than the average value of $6.2 \%$, which is similar to that of fiber, low water-binder ratio, or high sand ratio. However, fly ash can produce similar effect of air-entraining agent or water-reducing agent at high air content. If the assumption that spraying behavior will 
reduce air content is true, fresh wet shotcrete with high air content is beneficial to pumping and spraying. Therefore, it seems that adding silica fume is not conducive to the air content of wet shotcrete, while fly ash with relatively high air content is better.

Compressive strength: the influence of fly ash content on compressive strength is moderate, slightly higher than the average value. Considering the pumping and shotcreting performance of fly ash, fly ash is undoubtedly the common admixture of wet shotcrete. From the rheological parameters and air content, although the fluidity of concrete mixed with silica fume is low, it has great advantages in strength and sprayability. In some special projects that need to add silica fume into shotcrete, the pumpability can be improved by adding water-reducing agent or air-entraining agent.

\subsection{Summary of Influence of Admixtures or Additives on Pumpability and Shootability}

According to the above experimental analysis, free paste and round particles are the key factors affecting the pumpability and sprayability of wet shotcrete. As shown in Figure 22, cement paste has three functions: coating particles, filling gaps, and lubricating pipe wall. The "ball effect" and "free paste effect" have compound effects on the properties of wet shotcrete. In theory, these two effects, i.e., enough free paste or enough balls, can reduce the yield stress and improve the fluidity of concrete, which is called positive effect. However, in the fresh concrete system, if the free cement paste or smooth ball is insufficient, it is called negative effect, which will reduce the fluidity of fresh concrete. For example, in Figure 7, it can be concluded (from SR50 to SR60) that the negative paste effect is greater than the positive ball effect, resulting in an increase in yield stress and a decrease in slump.

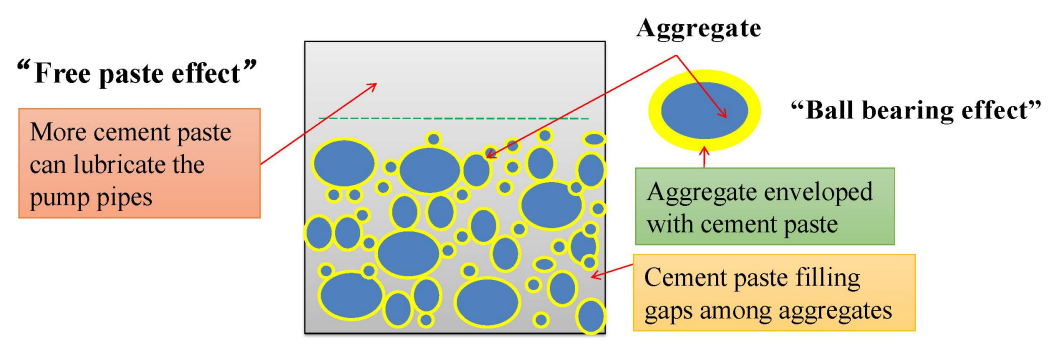

Figure 22. Free paste effect and ball bearing effect in fresh concrete system.

Yammine et al. [72] also found that the rheological properties of fresh concrete changed significantly between hydrodynamic and friction control. When the cement paste volume is small, the fluidity is mainly determined by the direct friction between particles. When the cement paste volume is large, the interaction between fluid and particles or between particles is hydrodynamic. The movement of the particles causes the paste to flow, where additional energy is dissipated. Therefore, with the increase of paste volume fraction, the plastic viscosity decreases. The additional paste volume significantly reduces the negative effect of coarse aggregate on the fluidity of fresh concrete [54]. Various factors affecting shotcrete properties are summarized in Table 4.

According to the above test results, to meet the different workability, such as pumping, spraying, or compressive strength, the general mix proportion range is given. Finally, the optimum mix proportion is recommended, as shown in Table 5. 
Table 4. Summary of various factors affecting shotcrete in pumpability and shootability.

\begin{tabular}{|c|c|c|c|c|}
\hline \multirow[b]{2}{*}{ Variable } & \multicolumn{2}{|c|}{ Flowability Factor } & \multicolumn{2}{|c|}{ Effect on Wet Shotcrete } \\
\hline & Ball Bearing Effect & $\begin{array}{l}\text { Free Paste Effect } \\
\text { or Filling Effect }\end{array}$ & Pumpability & Shootability \\
\hline Increasing WC & $\begin{array}{l}\text { Creating possibility for } \\
\text { entraining bubbles as } \\
\text { ball bearing effect }\end{array}$ & Producing more free paste & $\begin{array}{c}\text { Positive at some certain } \\
\text { level }\end{array}$ & $\begin{array}{l}\text { Negative for build-up } \\
\text { thickness; Positive for } \\
\text { reducing rebound }\end{array}$ \\
\hline $\begin{array}{l}\text { Increasing sand } \\
\text { ratio }\end{array}$ & $\begin{array}{c}\text { Sand as ball bearing } \\
\text { effect }\end{array}$ & $\begin{array}{l}\text { Sand fills gaps to release } \\
\text { more paste }\end{array}$ & Positive & $\begin{array}{c}\text { Negative for build-up } \\
\text { thickness; } \\
\text { Positive for strength }\end{array}$ \\
\hline Fiber & None & $\begin{array}{l}\text { Adding fiber reduces free } \\
\text { paste }\end{array}$ & $\begin{array}{l}\text { Positive due to } \\
\text { avoiding bleeding and } \\
\text { segregation }\end{array}$ & $\begin{array}{l}\text { Positive for build-up } \\
\text { thickness }\end{array}$ \\
\hline $\begin{array}{l}\text { Air-entraining } \\
\text { agent }\end{array}$ & $\begin{array}{c}\text { Bubbles as ball bearing } \\
\text { effect }\end{array}$ & $\begin{array}{l}\text { When bridge is broken, } \\
\text { paste was released }\end{array}$ & Positive & $\begin{array}{c}\text { Positive when bubbles } \\
\text { were broken during } \\
\text { spraying }\end{array}$ \\
\hline Water reducer & None & Releasing free cement paste & Positive & Negative \\
\hline Fly ash & $\begin{array}{l}\text { Spherical geometry and } \\
\text { smooth surface as ball } \\
\text { bearing effect }\end{array}$ & $\begin{array}{c}\text { Dilution effect with lower } \\
\text { specific gravity; filling } \\
\text { effect with small particle } \\
\text { size }\end{array}$ & Positive & $\begin{array}{l}\text { Negative at some } \\
\text { degree }\end{array}$ \\
\hline Silica fume & $\begin{array}{l}\text { Spherical geometry as } \\
\text { ball bearing effect }\end{array}$ & $\begin{array}{l}\text { Filling effect with small } \\
\text { particle; flocculation } \\
\text { reducing paste }\end{array}$ & $\begin{array}{l}\text { Positive for reducing } \\
\text { bleeding and } \\
\text { segregation }\end{array}$ & $\begin{array}{l}\text { Positive for build-up } \\
\text { thickness }\end{array}$ \\
\hline
\end{tabular}

Table 5. Mixture proportions recommended for meeting various shotcrete requirements.

\begin{tabular}{|c|c|c|c|c|c|c|c|c|c|}
\hline Requirements & $\begin{array}{l}\text { WC } \\
(w / b)\end{array}$ & $\begin{array}{l}\text { Water } \\
\left(\mathrm{kg} / \mathrm{m}^{3}\right)\end{array}$ & SR(\%) & $\begin{array}{c}\text { Sand } \\
\left(\mathrm{kg} / \mathrm{m}^{3}\right)\end{array}$ & $\begin{array}{c}\text { FI } \\
(\mathrm{mm})\end{array}$ & $\begin{array}{c}\text { AEA } \\
(\%)\end{array}$ & $\begin{array}{l}\text { WR } \\
(\%)\end{array}$ & $\begin{array}{l}\mathrm{SF} \\
(\%)\end{array}$ & $\begin{array}{l}\text { FA } \\
(\%)\end{array}$ \\
\hline Pumpability & $0.55-0.60$ & 220 & 60 & 1000 & $12-29$ & $0.04-0.06$ & $0.9-1.2$ & 15 & 5 \\
\hline Shootability & $0.45-0.50$ & 220 & $50-60$ & 1000 & $12-29$ & $0.02-0.04$ & $0.3-0.6$ & $5-10$ & 15 \\
\hline $\begin{array}{l}\text { Compressive strength } \\
\text { Optimum mix }\end{array}$ & 0.45 & 220 & 60 & 1000 & 6 & 0.02 & 0.6 & 15 & 5 \\
\hline $\begin{array}{l}\text { proportion for wet } \\
\text { shotcrete }\end{array}$ & 0.5 & 220 & 60 & 1000 & 12 & 0.04 & 0.6 & 10 & 10 \\
\hline
\end{tabular}

\section{Conclusions}

To investigate the influence of various admixtures on the fresh performance of shotcrete, the rheological properties and air content were measured. Through the comparative analysis of influencing factors and different analysis, it is helpful to understand the mix proportion design of fresh wet shotcrete.

(1) When WC increases, the slump and air content increase generally, while the rheological parameters decrease. with the increase of SR, the slump decreases gradually, while the air content and the relative yield stress increase. The air content, rheological parameters showed an increasing trend, while slump decreases with the increase of fiber length. With the increase of air-entraining agent content, the air content and slump increase, while rheological parameters decrease. Rheological parameters and air content decrease with the increase of superplasticizer dosage while the slump is opposite. With the increase of fly ash, the slump value increases, and rheological parameters decrease. The addition of silica fume reduces the slump, and increases the rheological parameters.

(2) With the increase of WC, the pressure drop decreases, i.e., smaller rheological parameters help to improve the pumping performance of fresh concrete. However, the high WC reduces the shootability. SR60 is the best value to obtain both good pumping performance and good shooting performance. Longer fibers help to reduce pressure drop and increase build-up thickness. The air-entraining agent can improve the pumpability 
and sprayability in a certain range. The increase of yield stress and viscosity is beneficial to build-up thickness. It was found that here are two key factors affecting the fluidity and shotcreting of fresh concrete: free paste effect and ball effect. These two positive effects are conducive to the pumpability of fresh concrete.

(3) Through comparative analysis, the effect of silica fume on yield stress is similar to that of fiber and medium sand ratio, and the influence degree of silica fume on plastic viscosity fluctuates around the average level. The effect of silica fume on air content is similar to that of fiber or high sand ratio. The effect of fly ash is basically the same as that of air-entraining agent on rheological properties or air content. The effect of silica fume and fly ash on slump is opposite to that of relative yield stress.

(4) Within a given range of variables, silica fume has the greatest influence on the slump and air content of fresh wet shotcrete. The water-binder ratio has the greatest influence on the relative yield stress and plastic viscosity. Finally, we concluded the summary of various factors affecting shotcrete in pumpability and shootability. Mixture proportions recommended for meeting various shotcrete requirements were advised. To study the rheological properties of shotcrete more accurately, we will add more experimental variables in the next step.

Author Contributions: Conceptualization, J.X. and G.L.; methodology, X.C.; formal analysis, N.G.; investigation, N.G. and G.L.; resources, G.L.; data curation, X.C.; writing-original draft preparation, G.L.; writing-review and editing, J.X. and X.C.; funding acquisition, G.L. All authors have read and agreed to the published version of the manuscript

Funding: This research was funded by National Key Research and Development Plan of China, grant number 2017YFC0805203, National Natural Science Foundation of China, grant number 51974177, 51934004, 51604163, Natural Science Foundation of Shandong, grant number ZR201801280006, ZR2019QEE007, ZR2019MEE115, Exchange Projects of the 43rd Routine Session of the China-Czech Committee for Scientific and Technological Cooperation, grant number 43-4 and Special funds for Taishan scholar project.

Institutional Review Board Statement: Not applicable.

Informed Consent Statement: Not applicable.

Data Availability Statement: Not applicable.

Conflicts of Interest: The authors declare that they have no known competing financial interests or personal relationships that could have appeared to influence the work reported in this paper.

\section{References}

1. Choi, P.; Yeon, J.H.; Yun, K.-K. Air-void structure, strength, and permeability of wet-mix shotcrete before and after shotcreting operation: The influences of silica fume and air-entraining agent. Cem. Concr. Compos. 2016, 70, 69-77. [CrossRef]

2. Chen, L.; Li, P.; Liu, G.; Cheng, W.; Liu, Z. Development of cement dust suppression technology during shotcrete in mine of China-A review. J. Loss Prev. Process. Ind. 2018, 55, 232-242. [CrossRef]

3. Liu, G.; Cheng, W.; Chen, L. Investigating and optimizing the mix proportion of pumping wet-mix shotcrete with polypropylene fiber. Constr. Build. Mater. 2017, 150, 14-23. [CrossRef]

4. Hu, Z.-X.; Hu, X.-M.; Cheng, W.-M.; Zhao, Y.-Y.; Wu, M.-Y. Performance optimization of one-component polyurethane healing agent for self-healing concrete. Constr. Build. Mater. 2018, 179, 151-159. [CrossRef]

5. Chen, L.; Ma, G.; Liu, G.; Liu, Z. Effect of pumping and spraying processes on the rheological properties and air content of wet-mix shotcrete with various admixtures. Constr. Build. Mater. 2019, 225, 311-323. [CrossRef]

6. Chen, L.; Zhang, X.; Liu, G. Analysis of dynamic mechanical properties of sprayed fiber-reinforced concrete based on the energy conversion principle. Constr. Build. Mater. 2020, 254, 119167. [CrossRef]

7. Liu, G.; Cheng, W.; Chen, L.; Pan, G.; Liu, Z. Rheological properties of fresh concrete and its application on shotcrete. Constr. Build. Mater. 2020, 243, 118180. [CrossRef]

8. Science and Technology of Concrete Admixtures; Elsevier: Amsterdam, The Netherlands, 2015.

9. Dils, J.; Boel, V.; De Schutter, G. Influence of cement type and mixing pressure on air content, rheology and mechanical properties of UHPC. Constr. Build. Mater. 2013, 41, 455-463. [CrossRef]

10. Chen, J.J.; Kwan, A.K.H. Superfine cement for improving packing density, rheology and strength of cement paste. Cem. Concr. Compos. 2012, 34, 1-10. [CrossRef] 
11. Koehler, E.; Fowler, D. Development of a Portable rheometer for fresh Portland cement concrete. In Fiber Reinforced Concrete; International Center for Aggregates Research: Austin, TX, USA, 2004; pp. 65-84.

12. Choi, M.S.; Kim, Y.J.; Jang, K.P.; Choi, M.S. Effect of the coarse aggregate size on pipe flow of pumped concrete. Constr. Build. Mater. 2014, 66, 723-730. [CrossRef]

13. Xu, W.; Zhang, Y.; Zuo, X.; Hong, M. Time-dependent rheological and mechanical properties of silica fume modified cemented tailings backfill in low temperature environment. Cem. Concr. Compos. 2020, 114, 103804. [CrossRef]

14. Park, C.K.; Noh, M.H.; Park, T.H. Rheological properties of cementitious materials containing mineral admixtures. Cem. Concr. Res. 2005, 35, 842-849. [CrossRef]

15. Rahman, M.K.; Baluch, M.H.; Malik, M.A. Thixotropic behavior of self compacting concrete with different mineral admixtures. Constr. Build. Mater. 2014, 50, 710-717.

16. Burroughs, J.F.; Weiss, J.; Haddock, J.E. Influence of high volumes of silica fume on the rheological behavior of oil well cement pastes. Constr. Build. Mater. 2019, 203, 401-407. [CrossRef]

17. Yun, K.K.; Choi, P.; Yeon J, H. Rheological characteristics of wet-mix shotcrete mixtures with crushed aggregates and mineral admixtures. Ksce J. Civ. Eng. 2017, 5, 1-11. [CrossRef]

18. Yun, K.-K.; Choi, P.; Yeon, J.H. Correlating rheological properties to the pumpability and shootability of wet-mix shotcrete mixtures. Constr. Build. Mater. 2015, 98, 884-891. [CrossRef]

19. Secrieru, E.; Fataei, S.; Schröfl, C.; Mechtcherine, V. Study on concrete pumpability combining different laboratory tools and linkage to rheology. Constr. Build. Mater. 2017, 144, 451-461. [CrossRef]

20. Tabatabaeian, M.; Khaloo, A.; Joshaghani, A.; Hajibandeh, E. Experimental investigation on effects of hybrid fibers on rheological, mechanical, and durability properties of high-strength SCC. Constr. Build. Mater. 2017, 147, 497-509. [CrossRef]

21. Burns, D. Characterization of Wet shotcrete for Small Line Pumping; Citeseer: Laval University, Quebec, QC, Canada, 2008.

22. Feys, D.; Khayat, K.H.; Khatib, R. How do concrete rheology, tribology, flow rate and pipe radius influence pumping pressure? Cem. Concr. Compos. 2016, 66, 38-46. [CrossRef]

23. Gołaszewski, J. Influence of mortar volume on rheological properties: Optimizing the workability of fresh high-performance concretes. Betonw. Fert.-Tech. 2008, 74, 44-51.

24. Feys, D.; De Schutter, G.; Verhoeven, R. Parameters influencing pressure during pumping of self-compacting concrete. Mater. Struct. 2012, 46, 533-555. [CrossRef]

25. Kwon, S.H.; Park, C.K.; Jeong, J.H.; Jo, S.D.; Lee, S.H. Prediction of Concrete Pumping: Part II-Analytical Prediction and Experimental Verification. ACI Mater. J. 2013, 110, 657-667.

26. Zhang, J.; Liu, L.; Cao, J.; Yan, X.; Zhang, F. Mechanism and application of concrete-filled steel tubular support in deep and high stress roadway. Constr. Build. Mater. 2018, 186, 233-246. [CrossRef]

27. Liu, G.; Guo, X.; Cheng, W.; Chen, L.; Cui, X. Investigating the migration law of aggregates during concrete flowing in pipe. Constr. Build. Mater. 2020, 251, 119065. [CrossRef]

28. Secrieru, E.; Cotardo, D.; Mechtcherine, V.; Lohaus, L.; Schröfl, C.; Begemann, C. Changes in concrete properties during pumping and formation of lubricating material under pressure. Cem. Concr. Res. 2018, 108, 129-139. [CrossRef]

29. Wallevik, O.H.; Wallevik, J.E. Rheology as a tool in concrete science: The use of rheographs and workability boxes. Cem. Concr. Res. 2011, 41, 1279-1288. [CrossRef]

30. Wang, J.; Niu, D.; Zhang, Y. Mechanical properties, permeability and durability of accelerated shotcrete. Constr. Build. Mater. 2015, 95, 312-328. [CrossRef]

31. Beaupre, D. Rheology of High Performance Shotcrete. Ph.D. Thesis, University of British Columbia, Vancouver, BC, Canada, 1994. [CrossRef]

32. Cheng, W.; Liu, G.; Chen, L. Pet Fiber Reinforced Wet-Mix Shotcrete with Walnut Shell as Replaced Aggregate. Appl. Sci. 2017, 7, 345. [CrossRef]

33. Li, P.; Zhou, Z.; Chen, L.; Liu, G.; Xiao, W. Research on Dust Suppression Technology of Shotcrete Based on New Spray Equipment and Process Optimization. Adv. Civ. Eng. 2019, 2019, 1-11. [CrossRef]

34. Chen, L.; Liu, G. Airflow-Dust Migration Law and Control Technology Under the Simultaneous Operations of Shotcreting and Drilling in Roadways. Arab. J. Sci. Eng. 2018, 44, 4961-4969. [CrossRef]

35. Yun, K.-K.; Choi, S.-Y.; Yeon, J.H. Effects of admixtures on the rheological properties of high-performance wet-mix shotcrete mixtures. Constr. Build. Mater. 2015, 78, 194-202. [CrossRef]

36. Pan, G.; Li, P.; Chen, L.; Liu, G. A study of the effect of rheological properties of fresh concrete on shotcrete-rebound based on different additive components. Constr. Build. Mater. 2019, 224, 1069-1080. [CrossRef]

37. ACI Committee. ACI-506R Guide to Shotcrete, 506 ed.; ACI Committee: Farmington Hills, MI, USA, 2005 ; p. 10.

38. Zhao, Y.; Duan, Y.; Zhu, L.; Wang, Y.; Jin, Z. Characterization of coarse aggregate morphology and its effect on rheological and mechanical properties of fresh concrete. Constr. Build. Mater. 2021, 286, 122940. [CrossRef]

39. Leung, C.K.; Lai, R.; Lee, A.Y. Properties of weted fiber reinforced shotcrete and fiber reinforced concrete with similar composition. Cem. Concr. Res. 2005, 35, 788-795. [CrossRef]

40. Choi, P.; Yun, K.-K.; Yeon, J.H. Effects of mineral admixtures and steel fiber on rheology, strength, and chloride ion penetration resistance characteristics of wet-mix shotcrete mixtures containing crushed aggregates. Constr. Build. Mater. 2017, 142, 376-384. [CrossRef] 
41. Zhang, Y.; Pan, D.; Qu, X.; Liang, P. Secondary Catalytic Effect of Circulating Ash on the Primary Volatiles from Slow and Fast Pyrolysis of Coal. Energy Fuels 2018, 32, 1328-1335. [CrossRef]

42. Banfill, P.F.G. The rheology of fresh cement and concrete-a review. In Proceedings of the 11th International Congress on the Chemistry of Cement, Durban, South Africa, 11-16 May 2003.

43. Paiva, H.; Velosa, A.; Veiga, R.; Ferreira, V. Effect of maturation time on the fresh and hardened properties of an air lime mortar Cem. Concr. Res. 2010, 40, 447-451. [CrossRef]

44. Greim, M.; Kusterle, W. Rheological measurement of building materials. Appl. Rheol. 2004, 14, 148-150. [CrossRef]

45. Kostrzanowska-Siedlarz, A.; Gołaszewski, J. Rheological properties of High Performance Self-Compacting Concrete: Effects of composition and time. Constr. Build. Mater. 2016, 115, 705-715. [CrossRef]

46. Paiva, H.; Velosa, A.; Cachim, P.; Ferreira, V. Effect of metakaolin dispersion on the fresh and hardened state properties of concrete. Cem. Concr. Res. 2012, 42, 607-612. [CrossRef]

47. Fan, T.; Zhou, G.; Wang, J. Preparation and characterization of a wetting-agglomeration-based hybrid coal dust suppressant. Process. Saf. Environ. Prot. 2018, 113, 282-291. [CrossRef]

48. Liu, G.; Chen, L. Development of a New Type of Green Switch Air Entraining Agent for Wet-Mix Shotcrete and Its Engineering Application. Adv. Mater. Sci. Eng. 2016, 2016, 1-9. [CrossRef]

49. Kostrzanowska-Siedlarz, A.; Gołaszewski, J. Rheological properties and the air content in fresh concrete for self compacting high performance concrete. Constr. Build. Mater. 2015, 94, 555-564. [CrossRef]

50. Pfeuffer, M.; Kusterle, W. Rheology and rebound behaviour of dry-mix shotcrete. Cem. Concr. Res. 2001, 31, 1619-1625. [CrossRef]

51. Hu, J.; Wang, K. Effect of coarse aggregate characteristics on concrete rheology. Constr. Build. Mater. 2011, 25, 1196-1204. [CrossRef]

52. Yardimci, M.Y.; Baradan, B.; Taşdemir, M.A. Effect of fine to coarse aggregate ratio on the rheology and fracture energy of steel fibre reinforced self-compacting concretes. Sadhana 2014, 39, 1447-1469. [CrossRef]

53. Secrieru, E.; Mechtcherine, V.; Schröfl, C.; Borin, D. Rheological characterisation and prediction of pumpability of strain-hardening cement-based-composites (shcc) with and without addition of superabsorbent polymers (sap) at various temperatures. Constr. Build. Mater. 2016, 112, 581-594. [CrossRef]

54. Westerholm, M.; Lagerblad, B.; Silfwerbrand, J.; Forssberg, E. Influence of fine aggregate characteristics on the rheological properties of mortars. Cem. Concr. Compos. 2008, 30, 274-282. [CrossRef]

55. Hengjing, B.A.; Zhang, W. Influence of aggregate on the rheological parameters of high-performance concrete. Concrete 2003, 64, 7-8.

56. Du, L.; Folliard, K.J. Mechanisms of air entrainment in concrete. Cem. Concr. Res. 2005, 35, 1463-1471. [CrossRef]

57. Burley, R.; Kennedy, B. An experimental study of air entrainment at a solid/liquid/gas interface. Chem. Eng. Sci. 1976, 31, 901-911. [CrossRef]

58. Jiao, D.; Shi, C.; Yuan, Q.; An, X.; Liu, Y.; Li, H. Effect of constituents on rheological properties of fresh concrete-A review. Cem. Concr. Compos. 2017, 83, 146-159. [CrossRef]

59. Harini, M.; Shaalini, G.; Dhinakaran, G. Effect of size and type of fine aggregates on flowability of mortar. KSCE J. Civ. Eng. 2011, 16, 163-168. [CrossRef]

60. Sivakumar, V.; Kavitha, O.; Arulraj, G.P.; Srisanthi, V. An experimental study on combined effects of glass fiber and Metakaolin on the rheological, mechanical, and durability properties of self-compacting concrete. Appl. Clay Sci. 2017, 147, 123-127. [CrossRef]

61. Tattersall, G.H.; Banfill, P.F. The Rheology of Fresh Concrete; Pitman: London, UK, 1983.

62. Struble, L.J. Effects of Air Entrainment on Rheology. Aci. Mater. J. 2004, 101, 448-456.

63. Rahman, M.A. Effect of geometry, gap, and surface friction of test accessory on measured rheological properties of cement paste. ACI Mater. J. 2003, 100, 331-339.

64. Kwan, A.; Fung, W. Effects of SP on flowability and cohesiveness of cement-sand mortar. Constr. Build. Mater. 2013, 48, 1050-1057. [CrossRef]

65. Perrot, A.; Lecompte, T.; Khelifi, H.; Brumaud, C.; Hot, J.; Roussel, N. Yield stress and bleeding of fresh cement pastes. Cem. Concr. Res. 2012, 42, 937-944. [CrossRef]

66. Laskar, A.I.; Talukdar, S. Rheological behavior of high performance concrete with mineral admixtures and their blending. Constr. Build. Mater. 2008, 22, 2345-2354. [CrossRef]

67. Beycioğlu, A.; Aruntaş, H.Y. Workability and mechanical properties of self-compacting concretes containing LLFA, GBFS and MC Constr. Build. Mater. 2014, 73, 626-635. [CrossRef]

68. Ahari, R.S.; Erdem, T.K.; Ramyar, K. Thixotropy and structural breakdown properties of self consolidating concrete containing various supplementary cementitious materials. Cem. Concr. Compos. 2015, 59, 26-37. [CrossRef]

69. Vance, K.; Kumar, A.; Sant, G.; Neithalath, N. The rheological properties of ternary binders containing Portland cement, limestone, and metakaolin or fly ash. Cem. Concr. Res. 2013, 52, 196-207. [CrossRef]

70. Biskri, Y.; Achoura, D.; Chelghoum, N.; Mouret, M. Mechanical and durability characteristics of High Performance Concrete containing steel slag and crystalized slag as aggregates. Constr. Build. Mater. 2017, 150, 167-178. [CrossRef] 
71. AzariJafari, H.; Tajadini, A.; Rahimi, M.; Berenjian, J. Reducing variations in the test results of self-consolidating lightweight concrete by incorporating pozzolanic materials. Constr. Build. Mater. 2018, 166, 889-897. [CrossRef]

72. Yammine, J.; Chaouche, M.; Guerinet, M.; Moranville, M.; Roussel, N. From ordinary rhelogy concrete to self compacting concrete: A transition between frictional and hydrodynamic interactions. Cem. Concr. Res. 2008, 38, 890-896. [CrossRef] 